\title{
Potential source rocks in the Ropianka Formation of the Magura Nappe (Outer Carpathians, Poland) - geochemical and foraminiferal case study
}

\author{
Anna Waśkowska ${ }^{1}$, Jan Golonka ${ }^{1}$, Grzegorz Machowski ${ }^{2}$, Ewa Pstrucha ${ }^{2}$ \\ ${ }^{1}$ AGH University of Science and Technology, Faculty of Geology, Geophysics and Environmental Protection, \\ Department of General Geology and Geotourism; al. A. Mickiewicza 30, 30-059 Krakow, Poland; \\ e-mail:waskowsk@agh.edu.pl, jgolonka@agh.edu.pl \\ ${ }^{2}$ AGH University of Science and Technology, Faculty of Geology, Geophysics and Environmental Protection, \\ Department of Fossil Fuels; al. A. Mickiewicza 30, 30-059 Krakow, Poland; \\ e-mail:machog@agh.edu.pl,ewa.pstrucha@agh.edu.pl (corresponding author)
}

(C) 2018 Authors. This is an open access publication, which can be used, distributed and reproduced in any medium according to the Creative Commons CC-BY 4.0 License requiring that the original work has been properly cited.

Received: 12 January 2018; accepted: 30 January 2018

\begin{abstract}
To optimize exploration for new hydrocarbon accumulations in the Polish Outer Carpathians, it is necessary to concentrate attention on identification of hydrocarbon accumulations of the "shale-gas" type. Results of recently completed analysis suggested new such possible targets in the Magura Basin, preserved in the Outer Carpathian Magura Nappe. Analysis of the preliminary results of paleoenvironmental and geochemical studies of these shales is the subject of this paper. Micropaleontological and geochemical study was conducted on the $300 \mathrm{~m}$ thick Świątkowa Member, the uppermost part of the Ropianka Formation located in the external, northernmost Siary Zone. This member is composed of thin- and medium-bedded sandstones interbedded by green, brown, black and dark-gray shales. Poor and changeable oxygenation is reflected in the composition of foraminiferal assemblages. A negative correlation between the TOC content and numbers and diversity of foraminifera is observed. The paleogeographic position and paleoenvironment assessment indicates that the Siary Zone fulfills certain conditions for organic productivity and preservation during the deposition of the Ropianka Formation.
\end{abstract}

Keywords: organic-rich deposits, geochemistry, foraminifera, Magura Nappe, shale-gas

\section{INTRODUCTION}

The estimation of the gas generating potential of the shale successions of Poland is currently a subject of the intensive studies conducted by industrial, governmental, and scientific organizations. The effective facilitation of this promising petroleum system requires a better understanding of the causal relationships between several controlling factors like the accumulation and distribution of organic matter in the shale reservoirs, thermal, diagenetic, and tectonic history, as well as geomechanical properties (frackability among the others) determining conditions of gas exploitation.

The Outer Carpathian nappes contain several organic-rich successions. The conditions favorable for the increased accumulation of organic matter occurred several times during the evolution of the Carpathian basins (e.g. Golonka et al. 2006, Kotarba \& Koltun 2006, Ślączka et al. 2006, 2014, Krobicki et al. 2012). These conditions were responsible for the origin of the source rocks for the conventional oil and gas deposits. The source rocks can also serve as a target for shale-gas and shale-oil exploration. The majority of these 
rocks are linked to the peri-Tethyan domain of Tethys, which includes the Protosilesian, Silesian, Skole-Skyba and Krosno-Menilite basins. The organic-rich rocks were deposited in these basins during Jurassic-Miocene times, mainly during the Late Jurassic-Early Cretaceous and Oligocene (e.g. Kotarba \& Koltun 2006, Krobicki et al. 2012, Ślączka et al. 2014 and citations therein). The Upper Jurassic and Oligocene shales were the prime subject for the estimations of shale-gas potential. During the recent analysis of shale complexes, new possibilities were also discovered in the Upper Creataceous-Paleocene shales deposited in the Magura Basin and preserved in the Outer Carpathian Magura Nappe. Analysis of the preliminary results of stratigraphic and geochemical research of these shales is the subject of this paper.

\section{OUTLINE OF GEOLOGY}

The Carpathians mountain arc stretches from Austria to the Iron Gate on the Danube in Romania (Fig. 1). The West Carpathians consist of an older, internal orogenic zone known as the Inner or Central Carpathians and the external, younger one, known as the Outer or Flysch Carpathians. The Outer Carpathians are built up of a stack of nappes and thrust-sheets showing a different lithostratigraphy and tectonic structures (e.g. Golonka 2011, Golonka et al. 2011). The Polish Outer Carpathian sedimentary rocks represent a time span between the Late Jurassic and Early Miocene. They were deposited in separate sedimentary basins. Every basin generally displays a different lithostratigraphic development.
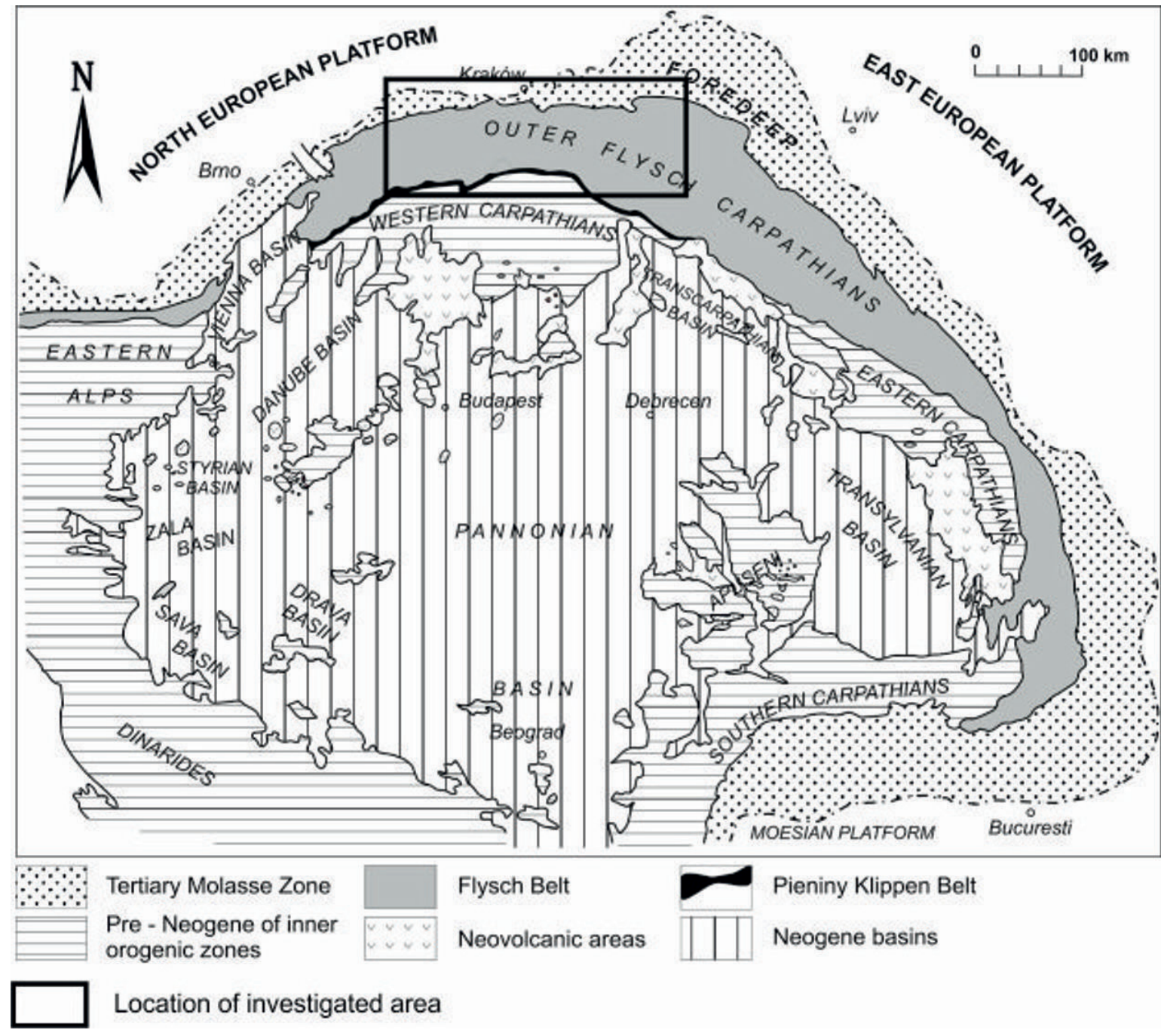

Tertiary Molasse Zone

Pre - Neogene of inner orogenic zones
Flysch Belt

Neovolcanic areas

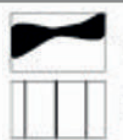

Pieniny Klippen Belt

Neogene basins

\section{Location of investigated area}

Fig. 1. Map of the Carpathians with the locality of the investigated area (modified, from Kováč et al. 1998) 
During the overthrusting movement, the tectonic units became uprooted forming several nappes. The following Outer Carpathian nappes have been distinguished: Magura Nappe, Fore-Magura group of nappes, Silesian, Subsilesian and Skole nappes as well as a narrow Zgłobice-Stebnik Zone of folded Miocene deposits (Fig. 2; Golonka et al. 2011). Each of the nappes displays rather complex structure being composed of several thrust-sheets, which display similar lithofacies succession, although lateral facies changes occur between particular thrust-sheets. In the western and central part of the Polish segment of the Outer Carpathians, the thrust-sheets strike SW or almost longitudinally, whereas in the eastern part, their strike changes to SE. Moreover, they are divided into series of blocks by faults stretching more or less perpendicularly to the strike of the thrust-sheets.

The Magura Nappe forms the largest tectonic unit of the northern Outer Carpathians. It has been completely uprooted from its substratum and thrust over the Fore-Magura and Silesian nappes, at least $20 \mathrm{~km}$, perhaps up to $50 \mathrm{~km}$ during the orogenic movement. It is built of the deposits that originated mainly within a separated basin of the Carpathian domain of the Western Tethys Ocean. This basin is known as Magura Basin, which developed during Mesozoic, Paleogene and Neogene times. Four tectonic-facies zones are being distinguished within the Magura Nappe. The study area is placed in the external, most northern zone called the Siary Zone sensu Koszarski et al. (1974).

The subject of our research is the Swiątkowa Member. It is distinguished within the uppermost part of the Ropianka Formation (e.g. Jurkiewicz \& Karnkowski 1959, Ślączka et al. 1993, Kaminski \& Ślączka 1998 and references therein).

The Upper Cretaceous-Upper Paleocene Ropianka Formation is dominated by the thin- and medium-bedded fine-grained, parallel- or cross-laminated or convolute quarzitic sandstones with numerous organic and current hieroglyphs. The sandstones are interbedded by gray and green shales, mainly marly shales, locally within shales and sandstones, the thin-bedded light marls occur. In the upper part of the Ropianka Formation, two members were distinguished. First, the Paleocene Mutne Member consists of thick- and medium-bedded, coarse- and medium-grained sandstones with thin intercalations of green-gray shales. The second one is the Swiątkowa Member, Late Cretaceous-Paleocene in age; it is composed of thin- and medium-bedded Ropianka-type sandstones divided by green, brown and dark-gray shales.

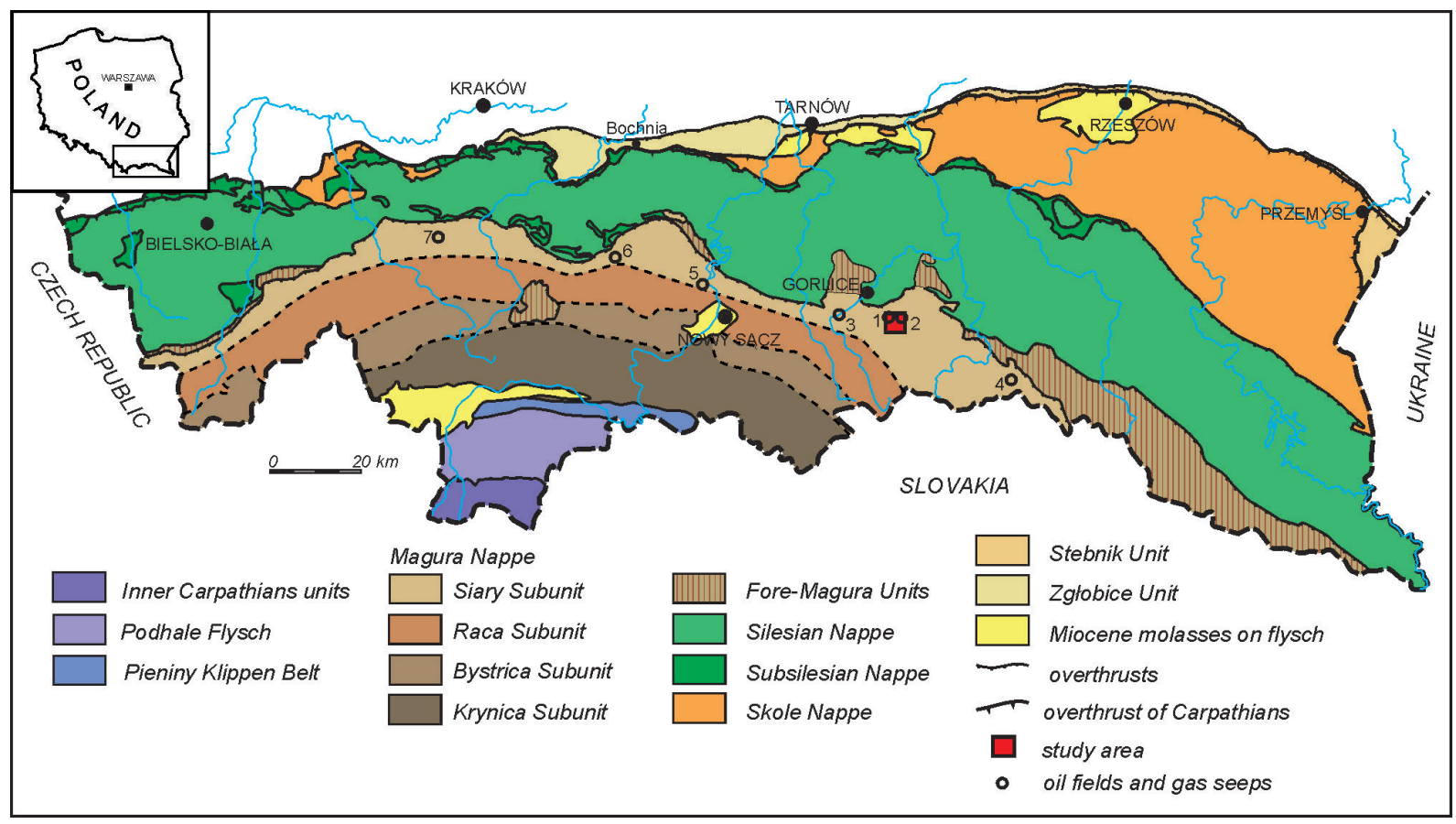

Fig. 2. Study area on the geological sketch-map of Polish Carpathians (modified, after Oszczypko et al. 2008). 1 - Sękowa-Ropica Górna-Siary, 2 - Męcina Wielka, 3 -Szymbark, 4 - Ropianka, 5 - Klęczany, 6 - Słopnice - Limanowa, 7 - Trzebunia 


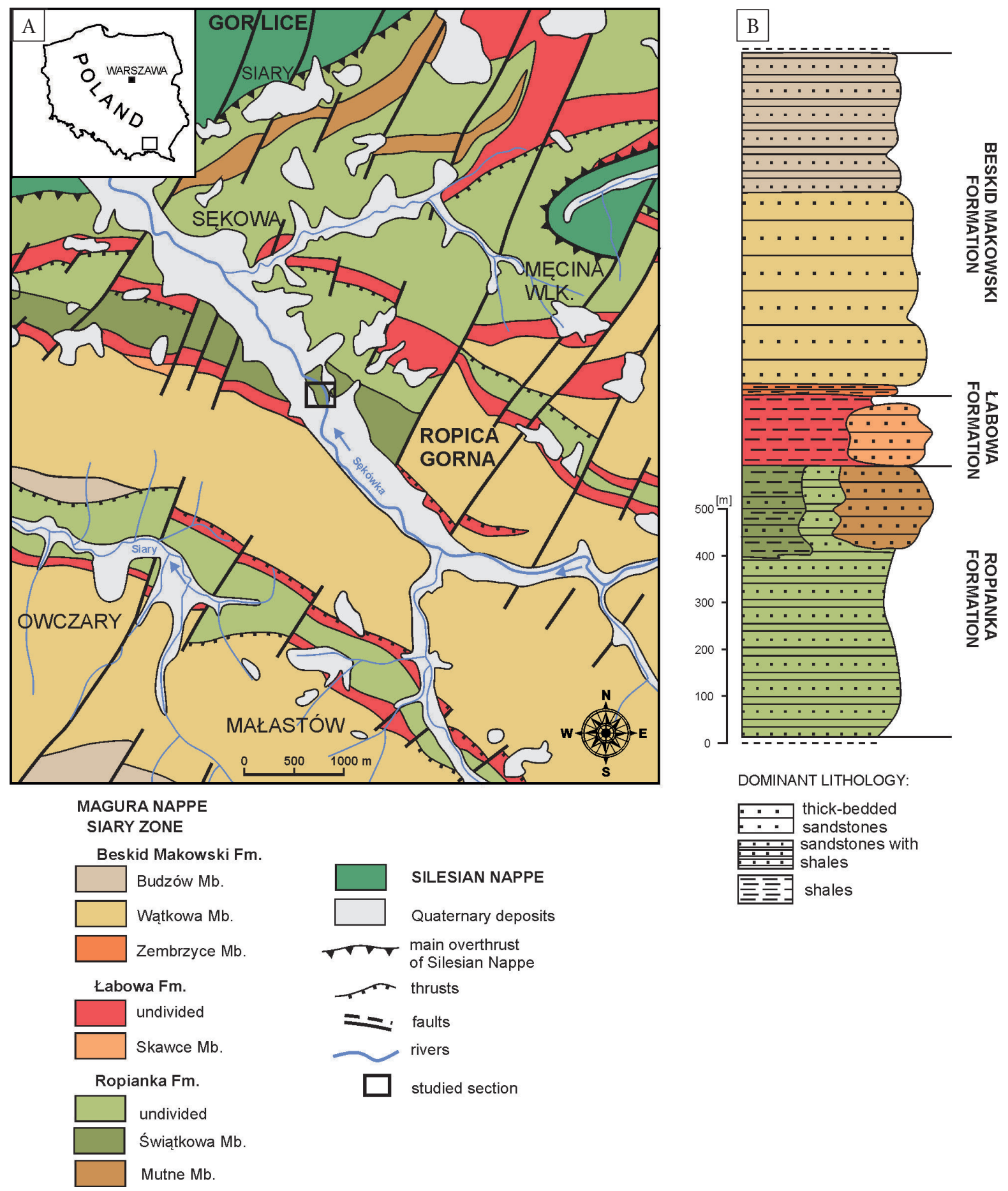

Fig. 3. Geological structure of investigated area: A) geological map of the Ropica Górna area (modified, after Kopciowski et al. 1997a, 1997b); B) lithological log of the Siary Zone of the Magura Nappe in the Ropica Górna area (modified, after Kopciowski et al. 2014)

This member was distinguished locally in the Magura Nappe, only within the Beskid Niski Mts range area (Kaminski \& Ślączka 1998). Its thickness reaches up to $300 \mathrm{~m}$ (Jurkiewicz \& Karnkowski 1959, Ślączka 2003). Our studies on the Świątkowa
Member were conducted mainly in the outcrop in Ropica Górna village (8 km south-west from Gorlice city), in Sękówka valley (Figs. 2, 3A). It is located in Sękówka stream bed, slightly below the bridge on the road no. 997 in the center of the village 
(coordinates: N 49³6'10.0", E $\left.21^{\circ} 13^{\prime} 30.4^{\prime \prime}\right)$. Earlier at this locality, micropaleontological studies were conducted by Geroch and published in a paper by Slączka et al. (1993). The tectonics and mineralization was presented in papers by Świerczewska (2005) and Świerczewska et al. (1999).

The Świątkowa beds were described by Jurkiewicz \& Karnkowski (1959) in the Gorlice area as a separate complex of the Inoceramian beds (the older name used for the Ropianka Formation in this area) observed on surface and in well cores. Firstly, they were defined as a transitional complex within the Paleocene thin and medium bedded flysch deposits between the typical Cretaceous Inoceramian beds and the Upper Paleocene variegated shales (the Łabowa Shale Formation). Jurkiewicz (1967) proposed to include the Paleocene part of variegated shales into the Świątkowa beds. Later, the Swiątkowa beds were incorporated into the Paleocene Inoceramian deposits with the characteristic occurrence of dark mudstones (e.g. Ślączka 1993, Ślączka et al. 1993, Kaminski \& Ślączka 1998, Ślączka 2003 and references therein).

\section{METHODS}

Samples of shales for stratigraphic and geochemical studies were collected in the outcrop during geological field work in the Gorlice area in 2015.

Rock-Eval pyrolysis and vitrinite reflectance were used to examine the petroleum source potential of rock samples from Sękówka area. These techniques have been routinely used as standard tools for hydrocarbon exploration (e.g. Barker 1974, Horsfield 1984, Espitalié et al. 1985, Lafargue et al. 1998). The Rock-Eval analysis is fundamental method to evaluate the hydrocarbon potential of source rocks, since it provides information about the amount, quality, type, and maturity of organic matter in a sample. The vitrinite reflectance measurements allowed determining the thermal maturity.

The measurements for the Rock-Eval pyrolysis were conducted at the Oil and Gas Institute in Kraków. Thirteen surface samples (Figure 8 shows sample distribution) were subsequently rinsed with plain water, oven-dried at room temperature and crushed into rock pieces smaller than $2 \mathrm{~cm}$.
A representative $150 \mathrm{~g}$ portion of each sample was selected and powdered into particles smaller than $0.2 \mathrm{~mm}$. The analyses of powder samples were carried out with a Rock-Eval 6 instrument equipped with an organic carbon module. The Rock-Eval pyrolysis was conducted following the standard workflow (e.g. Espitalié et al. 1985, Wilczek \& Merta 1992).

The reflectance measurements of organic matter were carried out on the five samples with the use of a Carl Zeiss Axio Imager microscope equipped with photometer PMT, computer with PMT III software and HBO lamp. The measurements were carried out in oil immersion (refractive index $n=1,518), 546 \mathrm{~nm}$ peak transmittance filter at a temperature of about $23^{\circ} \mathrm{C}$ in monochromatic non-polarized light in accordance to ASTM D 7708-11;14 (2011, 2014). For each sample best effort was made to perform minimum 20 single measurements of reflectance on vitrinite or/and bitumen particles (Barker \& Pawlewicz 1993).

Shaly intervals of the Swiątkowa Member were studied in terms of their micropaleontological record. Three layers of shales were sampled. Samples were taken in pairs - two samples were collected from every layer: one - from the lower part comprised of dark shale and one - from the upper part, consisting of the green shale. The samples were prepared by using standard procedures. $0.5 \mathrm{~kg}$ of shales were macerated by multiple heating and cooling in a Glaubert Salt solution $\left(\mathrm{Na}_{2} \mathrm{SO}_{4} \times \mathrm{H}_{2} \mathrm{O}\right)$, next washed on a $68 \mu \mathrm{m}$ sieves. From the obtained residue, all bioclasts were picked and taxonomically determined. The material was analyzed and documented using a NIKON VL100POL binocular microscope at the Department of General Geology and Geotourism of the Faculty of Geology, Geophysics and Environmental Protection, AGH University of Science and Technology. The samples have been deposited in the author's collection at the Micropress Europe Foundation (al. A. Mickiewicza 30, 30-059 Krakow). The microfossils are represented mainly by agglutinated foraminifera, which were studied in details. Ostracod shells and radiolarian steinkerns are very rare components in the investigated samples.

The discussion on stratigraphic position of these shales was based on previous works, and foraminiferal study. 


\section{RESULTS}

\section{Lithology}

In the studied section, the turbiditic deposits occur, which are represented by shales intercalated by sandstones (Fig. 4). Usually the sandstones are finegrained. The medium-passing to fine-grained sandstones (normal gradation) occurs rarely. They form thin- to thick-beds (up to $60 \mathrm{~cm}$ in thickness) while the $15-30 \mathrm{~cm}$ thick layers prevail in the section.
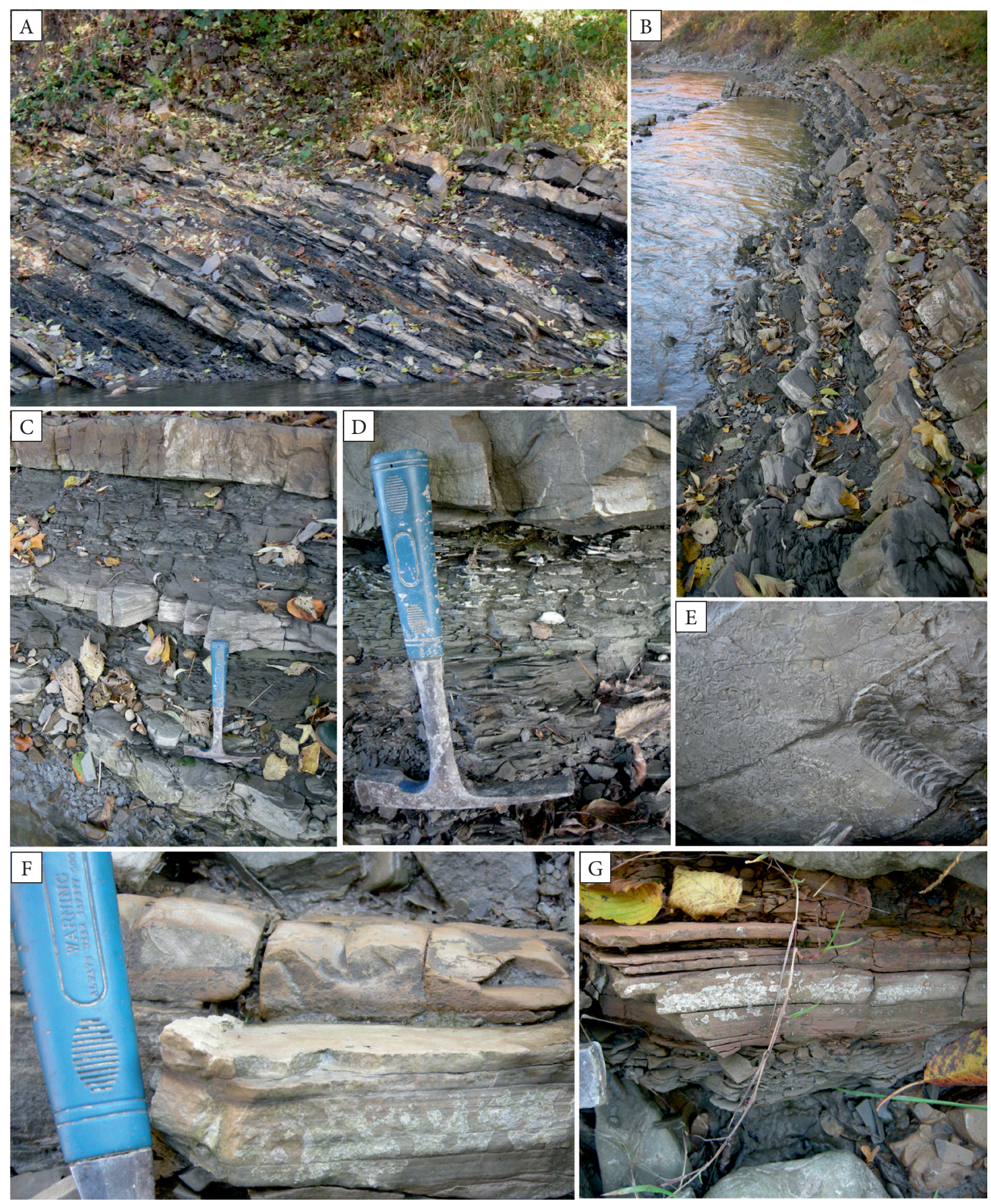

Fig. 4. Lithological development of the Świątkowa Member in Sękówka section in Ropica Górna: A, B) thin-bedded turbidites of the Światkowa Member - general view of outcrop; $C, D$ ) intervals of dark shales between the thin-and medium-bedded sandstones; E) sandstone bottom with bioglyphs; F), G) parallel laminated sandstones passing into siderite 
The sandstones are gray to brown in color, quarzitic, with calcareous cement. Rich different type laminations (parallel horizontal, cross and convolution) and numerous well developed mechanoglyphs, mainly flute marks are characteristic features of these sandstones. The trace fossils occur relatively frequently on the bottom surfaces of the layers. Numerous calcite streaks are present.

The shaly complexes occur between the sandstones. Their thickness ranges from single centimeters up to $50 \mathrm{~cm}$, mainly $20-35 \mathrm{~cm}$. Two kinds of mudstone were observed. Dominant are the black to dark gray mudstones (dark shales), calcareous or non-calcareous, hard, not ductile. Usually the transformation from darker to lighter is observed toward the top. The green shales belong to the second type represented by soft, plastic, more calcareous green mudstones. The shaly intercalations contain mainly dark gray, rarely green sediment. The green shales frequently occur in the upper parts of the shaly complexes (Fig. 4).

The siderites, which form long lenses or thinor medium-bedded (up to $25 \mathrm{~cm}$, mainly $5-12 \mathrm{~cm}$ layers) represent the next component of the studied section. Siderites are pelitic, gray on fresh surface, brown-orange on a weathered surface; laminations are visible in some siderites. Sporadically the siderites terminate the sandstone layers, being their continuation.

\section{Geochemistry}

The values of parameters and indices obtained from the Rock-Eval pyrolysis on 13 surface samples collected from the Sękówka area (Tab. 1) vary in the following ranges: total organic carbon (TOC) from $0.34 \mathrm{wt} . \%$ in green shales to $1.70 \mathrm{wt} . \%$ in dark gray shales, free hydrocarbon content $\left(\mathrm{S}_{1}\right)$ from 0.02 to $0.25 \mathrm{mg} \mathrm{HC} / \mathrm{g}$ rock, residual genetic potential $\left(\mathrm{S}_{2}\right)$ from 0.16 to $1.51 \mathrm{mg} \mathrm{HC/g}$ rock, $\mathrm{CO}_{2}$ content $\left(\mathrm{S}_{3}\right)$ from 0.13 to $0.40 \mathrm{mg} \mathrm{CO}_{2} / \mathrm{g}$ rock, production index (PI) from 0.08 to 0.18 , hydrogen index (HI) from 47 to $106 \mathrm{mg} \mathrm{HI} / \mathrm{g}$ TOC, oxygen index (OI) from 21 to 55 , total mineral carbon content (MIN C) from 0.06 to $1.09 \%$, temperature determined at the $\mathrm{S}_{2}$ peak maximum $\left(\mathrm{T}_{\max }\right)$ from 431 to $439^{\circ} \mathrm{C}$. The highest values correspond usually to sample 2 , and the lowest - to sample 9. Values of vitrinite reflectance range from $0.72-0.77 \%$ ( $0.76 \%$ on average).

Table 1

The Rock-Eval pyrolysis and vitrinite reflectance - results

\begin{tabular}{|c|c|c|c|c|c|c|c|c|c|c|c|c|}
\hline $\begin{array}{c}\text { Sam- } \\
\text { ple } \\
\text { no. }\end{array}$ & $\begin{array}{c}\mathbf{T}_{\max } \\
{\left[{ }^{\circ} \mathbf{C}\right]}\end{array}$ & $\begin{array}{c}\mathbf{S}_{1} \\
{[\mathbf{m g ~ H C} /} \\
\mathbf{g} \text { of rock }]\end{array}$ & $\begin{array}{c}\mathbf{S}_{2} \\
{[\mathbf{m g ~ H C} /} \\
\mathbf{g} \text { of rock }]\end{array}$ & $\begin{array}{c}\mathbf{S}_{3} \\
{\left[\mathbf{m g ~ C O}_{2} /\right.} \\
\mathbf{g} \text { of rock }]\end{array}$ & $\begin{array}{c}\mathbf{S}_{2} / \mathbf{S}_{3} \\
{[-]}\end{array}$ & $\begin{array}{c}\text { PI } \\
{[-]}\end{array}$ & $\begin{array}{c}\text { TOC } \\
{[\mathbf{w t} . \%]}\end{array}$ & $\begin{array}{c}\mathbf{H I} \\
{[-]}\end{array}$ & $\begin{array}{c}\text { OI } \\
{[-]}\end{array}$ & $\begin{array}{c}\text { MIN C } \\
{[\%]}\end{array}$ & $\begin{array}{c}\text { Ro } \\
{[\%]}\end{array}$ & $\begin{array}{c}\text { Color of } \\
\text { shale }\end{array}$ \\
\hline 1 & 436 & 0.11 & 0.54 & 0.17 & 3.18 & 0.17 & 0.79 & 68 & 22 & 0.85 & - & gray \\
\hline 2 & 436 & 0.25 & 1.51 & 0.36 & 4.19 & 0.14 & 1.70 & 89 & 21 & 0.73 & 0.76 & dark gray \\
\hline 3 & 432 & 0.05 & 0.22 & 0.18 & 1.22 & 0.18 & 0.37 & 59 & 49 & 0.61 & - & green \\
\hline 4 & 437 & 0.22 & 1.06 & 0.29 & 3.66 & 0.17 & 1.35 & 79 & 21 & 0.55 & 0.77 & dark gray \\
\hline 5 & 435 & 0.19 & 1.25 & 0.30 & 4.17 & 0.13 & 1.18 & 106 & 25 & 0.83 & 0.72 & dark gray \\
\hline 6 & 437 & 0.07 & 0.34 & 0.13 & 2.62 & 0.17 & 0.55 & 62 & 24 & 0.43 & - & green \\
\hline 7 & 434 & 0.06 & 0.48 & 0.40 & 1.20 & 0.12 & 0.73 & 66 & 55 & 1.09 & - & gray \\
\hline 8 & 433 & 0.05 & 0.60 & 0.18 & 3.33 & 0.08 & 0.82 & 73 & 22 & 0.31 & - & dark gray \\
\hline 9 & 434 & 0.02 & 0.16 & 0.14 & 1.14 & 0.12 & 0.34 & 47 & 41 & 0.06 & - & green \\
\hline 10 & 438 & 0.11 & 0.77 & 0.25 & 3.08 & 0.13 & 1.02 & 75 & 25 & 0.81 & 0.77 & dark gray \\
\hline 11 & 431 & 0.04 & 0.18 & 0.15 & 1.20 & 0.17 & 0.37 & 49 & 41 & 0.46 & - & green \\
\hline 12 & 439 & 0.08 & 0.63 & 0.21 & 3.00 & 0.11 & 0.92 & 68 & 23 & 0.97 & - & dark gray \\
\hline 13 & 437 & 0.09 & 0.69 & 0.27 & 2.56 & 0.11 & 1.00 & 69 & 27 & 0.79 & 0.74 & dark gray \\
\hline
\end{tabular}

$\mathrm{T}_{\max }$ - cracking temperature, at which maximum hydrocarbon amount is produced $\left[{ }^{\circ} \mathrm{C}\right], \mathrm{S}_{1}$ - free hydrocarbon content [ $\mathrm{mg} \mathrm{HC} / \mathrm{g}$ of rock], $\mathrm{S}_{2}$ - residual genetic potential [mg HC/g of rock], $\mathrm{S}_{3}-\mathrm{CO}_{2}$ content $\left[\mathrm{mg} \mathrm{CO}_{2} / \mathrm{g}\right.$ of rock], PI - production index $=\mathrm{S}_{1} /\left(\mathrm{S}_{1}+\mathrm{S}_{2}\right)$, TOC - total organic carbon [wt.\%], HI - hydrogen index [mg HC/g of TOC], OI - oxygen index $\left[\mathrm{mg} \mathrm{CO}_{2} / \mathrm{g}\right.$ of TOC], MIN C - total mineral carbon content, Ro - vitrinite reflectance [\%]. 


\section{Micropaleontological record}

All studied samples contain numerous microfossils. 146-2099 specimens of foraminiferal tests were collected from $0.5 \mathrm{~kg}$ of mudstone (Tab. 2). The preservation state of micropaleontological material is good, some of microfossils were preserved only as broken fragments; the tubular forms e.g. Nothia, Rhabdammina and Psammosiphonella and uniserial multichambered forms e.g. Arthrodendron, Caudammina, Reophax, Kalamopsis and Subreophax belong to this group.

Two separate assemblages of fossils were obtained from the studied shales (Fig. 5). In lower parts of shale layers, unified and undifferentiated assemblages are preserved. They contain only or almost-only tubular, massive forms of Nothia (Tab. 2), representing the epifaunal form, choosing a horizontal or nearly horizontal position in the sediment. Nothia build long, branched and tubular tests, which after diagenesis occur usually in fragments. They amount is from 110 up to 204 specimens (Tab. 2). Pyritization is a characteristic feature of these fossils. Single specimens of Ammodiscus, Paratrochamminoides, Recurvoides and Subreophax occur in sample SEK 8 together with tubular forms (Tab. 2). The TOC content is here slightly lower.

The foraminiferal assemblages from the upper parts of shaly layers are definitely different in terms of numbers of fossils and taxonomic composition. The number of foraminiferal tests is from 1486 up to 2099. They were classified into 20-25 genera and 36-38 species (Tab. 2, Figs. 6-8). The occurring species are represented by primitive benthic agglutinated forms, mostly cosmopolitan. Fragments of tubular forms constitute slightly more than half of all microfossils. Numerous are Saccamminacea represented by Placentammina placenta (Grzybowski) and Saccammina div. sp., which amount to about $10 \%$, and Lituotubacea represented by Paratrochamminoides and Trochamminoides div. sp., which amount to 5-9\%. Different species of Recurvoidacea, Ammodiscidae, Hormosinellidae, Hormosinacea, Haplophragmiacea, Trochamminidae and Prolixoplectidae usually are typical components of assemblages (Tab. 2). Pyritization of the foraminiferal test is rare.

\section{Biostratigraphy}

The time of sedimentation of the Świątkowa Member deposits in the Ropica Górna locality is unclear. The Paleocene age of the Świątkowa Member was documented by Jurkiewicz (1967), Jurkiewicz \& Karnkowski (1959) and Geroch in Ślączka et al. (1993) by the occurrence Rzehakina fissistomata (Grzybowski), which is a marker species for the Paleocene biozone in Outer Carpathians. In foraminiferal assemblages with Rzehakina fissistomata (Grzybowski), the Paleocene planktonic foraminifer - Globigerina (Subbotina) cf. triloculinoides (Plummer) is reported by Geroch in Ślączka et al. (1993) from the Ropica Górna locality.
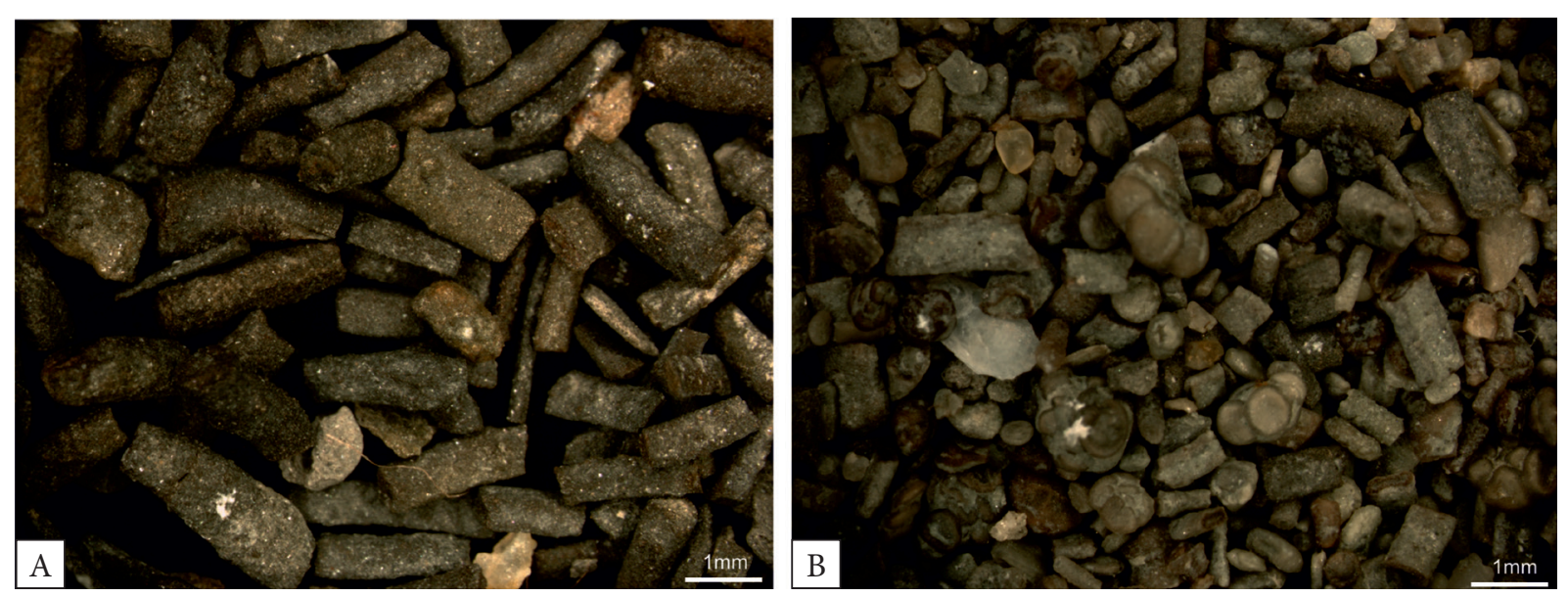

Fig. 5. Foraminiferal assemblages from the Światkowa Member: A) assemblages from dark shale; B) assemblages from green shale 
Table 2

Taxonomic composition and the amount of foraminifera in samples form dark and green shales of the Światkowa Member

\begin{tabular}{|c|c|c|c|c|c|c|}
\hline & $\begin{array}{c}\text { Sek } \\
5\end{array}$ & $\begin{array}{c}\text { Sek } \\
6\end{array}$ & $\begin{array}{c}\text { Sek } \\
8\end{array}$ & $\begin{array}{c}\text { Sek } \\
9\end{array}$ & $\begin{array}{c}\text { Sek } \\
10\end{array}$ & $\begin{array}{c}\text { Sek } \\
11\end{array}$ \\
\hline \multicolumn{7}{|l|}{ Benthic Foraminifera } \\
\hline Ammodiscus peruvianus Berry & & 10 & & 8 & & 15 \\
\hline Ammodiscus cretaceus (Reuss) & & 9 & 4 & 8 & & 12 \\
\hline Ammodiscus tenuissimus Grzybowski & & 2 & & 40 & & 8 \\
\hline Ammodiscus pennyi Cushman et Jarvis & & 1 & & & & 4 \\
\hline Ammosphaeroidina pseudopauciloculata (Mjatliuk) & & 4 & & 42 & & 136 \\
\hline Arthrodendron carpathica (Neagu) (fragments) & & 2 & & 6 & & 25 \\
\hline Annectina grzybowskii (Jurkiewicz) & & & & & & 2 \\
\hline Ammolagena clavata (Jones et Parker) & & & & & & 1 \\
\hline Nothia sp., Psammosiphonella sp., Rhabdammina sp. (fragments) & & & 110 & & & 438 \\
\hline Nothia sp. (fragments) & 170 & 308 & & 1166 & 204 & \\
\hline Buzasina pacyfica Krashenninikov & & & & 16 & & 4 \\
\hline Caudammina ovula (Grzybowski) (chambers) & & 16 & & 28 & & \\
\hline Caudammina gigantea (Geroch) (chambers) & & 2 & & 8 & & 2 \\
\hline Caudammina excelsa (Dylążanka) (fragments) & & 24 & & 40 & & \\
\hline Glomospira charoides (Jones et Parker) & & 16 & & & & 8 \\
\hline Glomospira diffundens Cushman et Renz & & 2 & & & & \\
\hline Glomospira irregularis (Grzybowski) & & 4 & & & & \\
\hline Glomospia cf. irregularis (Grzybowski) & & 5 & & 12 & & 5 \\
\hline Glomospira glomerata (Grzybowski) & & 2 & & & & 8 \\
\hline Glomospira gordialis (Jones et Parker) & & 20 & & 8 & & 4 \\
\hline Haplophragmoides kirki Wickenden & & 4 & & 12 & & 8 \\
\hline Haplophragmoides cf. walteri (Grzybowski) & & 4 & & & & \\
\hline Haplophragmoides cf. mjatliukae Maslakova & & & & 20 & & 6 \\
\hline Haplophragmoides sp. & & & & 4 & & \\
\hline Hormosina trinitatensis Cusman et Renz & & 2 & & 4 & & 11 \\
\hline Hormosina velascoensis (Cushman) & & & & & & 4 \\
\hline Hormosinelloides guttifer (Brady) & & & & & & 12 \\
\hline Hyperammina sp. & & & & 4 & & \\
\hline Kalamopsis grzybowskii (Dylążanka) (chambers) & & 16 & & 48 & & 28 \\
\hline Karrerulina conversa (Grzybowski) & & 4 & & & & \\
\hline Paratrochamminoides and Trochamminoides div. sp. & & 125 & 4 & 60 & & 95 \\
\hline Placentammina placenta (Grzybowski) & & 111 & & 96 & & 72 \\
\hline Praecystammina globigeriniformis Krashenninikov & & 2 & & & & \\
\hline Psammosphaera irregularis (Grzybowski) & & & & 12 & & \\
\hline Psammosiphonella sp. / Rhabdammina sp. (fragments) & & 370 & & 180 & 84 & 374 \\
\hline Pseudonodosinella nodulosa (Brady) & & 4 & & & & 2 \\
\hline Recurvoides div. sp., Recurvoidella lamella (Grzybowski), Cribrostomoides div. sp. & & 56 & 24 & 54 & & 55 \\
\hline Reophax duplex Grzybowski & & 10 & & & & 14 \\
\hline Reophax pilulifer Brady & & & & & & 2 \\
\hline Reophax sp. (chambers) & & 1 & & 1 & & 10 \\
\hline Saccammina grzybowskii (Schubert) & & 64 & & 136 & & 88 \\
\hline Saccammina scrabosa Mjatliuk & & 6 & & & & \\
\hline Subreophax scalaris (Grzybowski) (fragments) & & 4 & & 24 & & 14 \\
\hline Subreophax splendidus (Grzybowski) (fragments) & & & & 4 & & 2 \\
\hline Subrepohax pseudoscalaris (Samuel) (fragments) & & & 4 & 32 & & 5 \\
\hline Thurammina sp. & & & & & & 4 \\
\hline Trochammina globigeriniformis (Parker et Jones) & & 6 & & 6 & & 6 \\
\hline Trochammina umiatensis Tappan & & & & 4 & & \\
\hline Trochammina sp. & & & & 16 & & 2 \\
\hline Radiolarian steinkerns & & 28 & & 24 & & 16 \\
\hline Ostracoda & & 1 & & & & \\
\hline
\end{tabular}




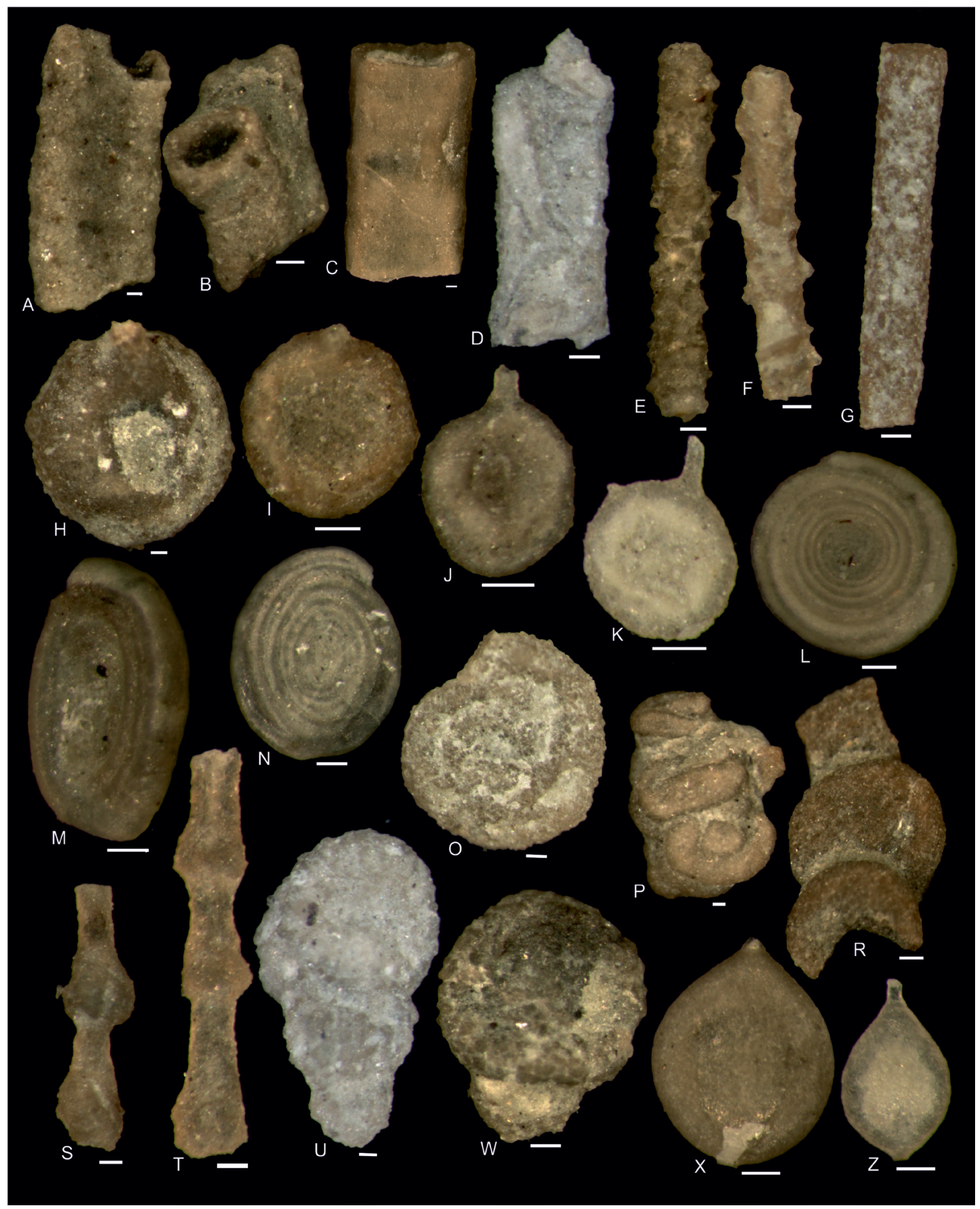

Fig. 6. SEM pictures of foraminifera from the Światkowa Member: A) Nothia exelsa (Grzybowski), sample no. (s.) 9; B) Nothia exelsa (Grzybowski), s. 9; C) Nothia sp., s. 11; D) Rhabdammina sp. with attached Ammolagena clavata (Jones et Parker), s. 11; E) Rhabdammina linearis Brady, s. 11; F) Rhabdammina sp., s. 6; G) Psammosiphonella cylindrica (Glaesner) sp., s. 9; H) Placentammina placenta (Grzybowski), s. 6; I) Placentammina placenta (Grzybowski), s. 11; J) Saccammina grzybowskii (Schubert), s. 6; K) Saccammina grzybowskii (Schubert), s. 11; L) Ammodiscus tenuissimus Grzybowski, s. 9; M) Ammodiscus peruvianus Berry, s. 9; N) Ammodiscus peruvianus Berry, s. 6; O) Ammodiscus pennyi Cushman et Jarvis, s. 11; P) Glomospira glomerata (Grzybowski), s. 11; R) Arthodendron carpathica (Neagu), s. 9; S) Caudammina excelsa (Dylażanka), s. 6; T) Caudammina excelsa (Dylązanka), s. 6; U) Reophax pilulifer Brady, s. 9; W) Reophax duplex Grzybowski, s. 6; X) Caudammina gigantea (Geroch), s. 6; Z) Caudammina ovula (Grzybowski), s. 6. Scale bar is $100 \mu \mathrm{m}$ 


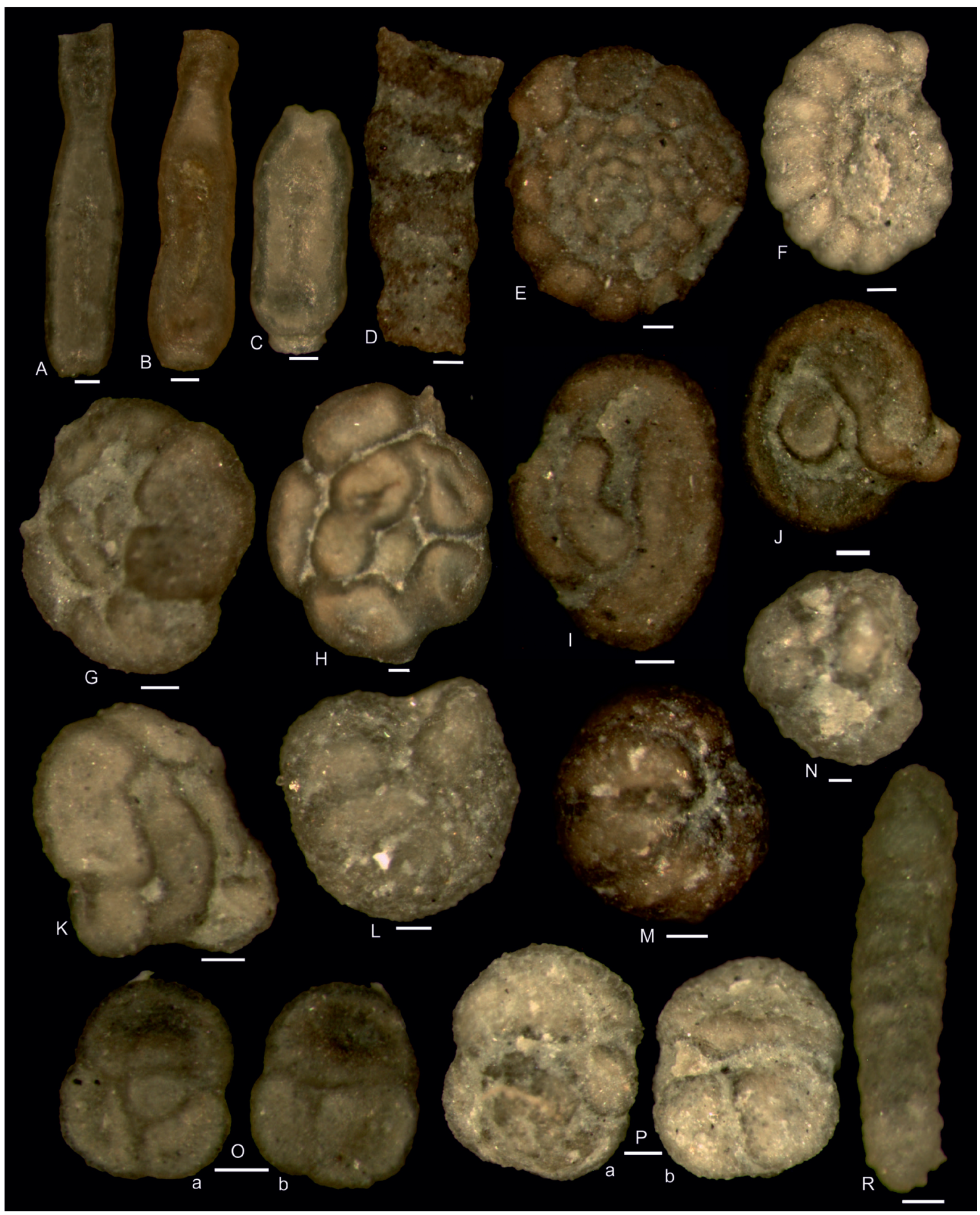

Fig. 7. SEM pictures of foraminifera from the Swiątkowa Member: A) Kalamopsis grzybowskii (Dylążanka), s. 9; B) Kalamopsis grzybowskii (Dylażanka), s. 6; C) Kalamopsis grzybowskii (Dylażanka), s. 11; D) Subreophax pseudoscalaris (Samuel), s. 9; E) Trochamminoides grzybowskii Kaminski et Geroch, s. 9; F) Trochamminoides grzybowskii Kaminski et Geroch, s. 11; G) Trochamminoides subcoronatus (Grzybowski), s. 9; H) Trochamminoides subcoronatus (Grzybowski), s. 6; I) Paratrochamminoides gorayskii (Grzybowski), s. 9; J) Lithuotuba sp., s. 9; K) Paratrochamminoides sp., s. 6; L) Recurvoides nucleolus (Grzybowski), s. 6; M) Recurvoides sp., s. 6; N) Thalmannammina subturbinata (Grzybowski), s. 6; O) Ammosphaeroidina pseudopauciloculata (Mjatliuk), s. 9; P) Trochammina globigeriniformis (Parker et Jones), s. 11; R) Karrerulina conversa (Grzybowski), s. 6. Scale bar is $100 \mu \mathrm{m}$ 


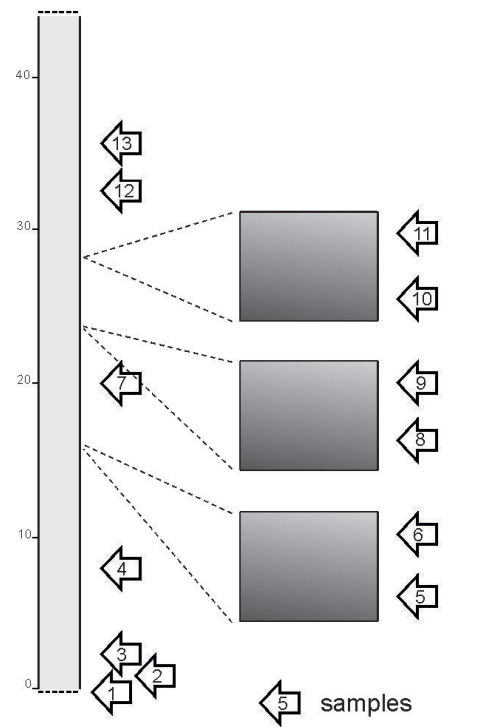

TOC [\%] NUMBER OF SPECIMENS SPECIES NUMBER GENERA NUMBER

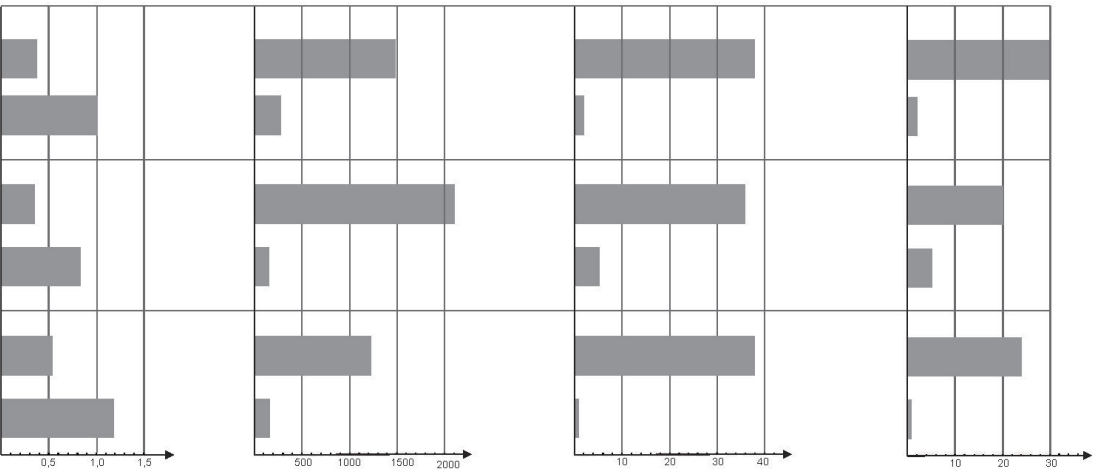

Fig. 8. Quantity and diversity of foraminiferal assemblages from the Swiatkowa Member

On the other hand, the big shell of mollusk (with high probability Inoceramus) was found and documented by Anna Świerczewska within the same exposure (personal information), what can suggest Cretaceous age of the rocks. We try to evaluate the age of sedimentation deposits in the Ropica Górna locality using the foraminiferal microfauna. The assemblages coming from the upper parts of shaly complexes were taken into consideration. They contain numerous and taxonomically varied foraminifera (Tab. 2, Figs. 6, 7). This part of rock sequence was deposited under the significant influence of suspension (uppermost part of turbiditic sequence) that predisposed the development of microfauna. Consequently these assemblages can be treated as autochthonic. This assumption is confirmed by taxonomic reputability in all mudstone layers separated by sandstones and close similarity of this feature to those observed by Jurkiewicz \& Karnkowski (1959) and Geroch in Ślączka et al. (1993) publishing micropaleontological data.

The occurrence of numerous cosmopolitan species living in the Late Cretaceous up to the end of Paleocene (sporadically to the Early Eocene) is typical for all analyzed assemblages. Ammodiscus pennyi Cushamn et Jarvis, Annectina grzybowskii (Jurkiewicz), Buzasina pacifica (Krasheninnikov), all recognized Caudammina, Glomospira diffundens Cushman et Renz, Hormosina velascoensis
(Cushman) (stratigraphical ranges after Geroch \& Nowak 1984, Sztajn et al. 1984, Olszewska et al. 1996, Olszewska 1997, Kaminski \& Gradstein 2005 and references therein) (Tab. 2) belong to these forms. Among the mentioned taxa, Caudammina excelsa Dylążanka in the Outer Carpathians is noticed from the beginning of the Maastrichtian and Annectina grzybowskii (Jurkiewicz) from middle Maastrichtian (Geroch \& Nowak 1984, Sztajn et al. 1984, Olszewska 1997). A relatively high number of Caudammina is noticed in sampled deposits (Tab. 2). Numerous Caudammina are known from the Danian within the Carpathian Paleocene (Waśkowska-Oliwa 2008). A crucial meaning has the occurrence of Caudammina gigantea Geroch, which is in large amount particularly widespread in the Late Cretaceous. It appeared in the Santonian and lasted up to end of Early Paleocene with an acme in the Late Cretaceous (Geroch \& Nowak 1984, Geroch \& Koszarski 1988, Olszewska 1997 and references therein). In our material, occurrence of Caudammina gigantea Geroch has marginal meaning. Summarizing the above data, there is no conclusive evidence of age sedimentation of the Świątkowa Member in the Ropica Gorna section taking account the assemblages obtained from our samples. High number of Caudammina specimens can suggest the Early Paleocene. 


\section{DISCUSSION}

The analyzed shales do not differ significantly in terms of the total organic carbon content (TOC). The TOC content for the majority of the samples exceed $0.5 \mathrm{wt} . \%$ and the mean value amounts to 1 wt.\%. The hydrocarbon content $\left(S_{1}+S_{2}\right) / T O C$ ratio differs slightly among the analyzed sample population. Nonetheless, it indicates that the hydrocarbon potential $\left(S_{1}+S_{2}\right)$ of the samples is relatively poor (Fig. 9). The oxidative compounds content $\mathrm{S}_{3}$ for all the samples is low and does not exceed $0.5 \mathrm{mg} \mathrm{CO} / \mathrm{g}$ rock.

The Rock-Eval analysis enabled to determine the type and thermal maturity of the organic matter dispersed in the studied samples. The results of $\mathrm{T}_{\max }$ measurements allowed to conclude, that all of the samples correspond to the initial phase of "oil window" which is due to low values of $\mathrm{T}_{\max }$. Correlation between $\mathrm{HI}_{-} \mathrm{T}_{\max }$ and $\mathrm{HI}-\mathrm{OI}$ shows that all analyzed samples are plotted on the region of typeIII, which represents the humicgas-prone type of kerogen (Fig. 10). The kerogen is characterized by moderate values of the OI index. However, it is worth to notice that analyzed surface samples were a bit weathered, what may contribute to OI value.

The results of vitrinite reflectance measurements for the surface samples of Sękówka vary from $0.72 \%$ to $0.77 \%$. The obtained values are characteristic for the organic matter mature enough to generate oil (begin of "oil window" maturity, Fig. 10A). The organic matter present in the analyzed samples is of the humic type with predominance of inertinite. The type and thermal maturity degree determined based on the vitrinite reflectance measurements are consistent with the Rock-Eval pyrolysis results.

The organic matter from the Świątkowa Member was preserved and diagenetically altered in the mudstone-clayey shale intervals forming the upper parts of turbiditic intervals. The content of organic carbon depends on the shale's character expressed by their color (Tab. 1, Fig. 8). The dark-gray shales contain a significant amount of TOC, from $0.73 \%$ up to $1.7 \%$, while in green shales the TOC content is $0.34-0.55 \%$.

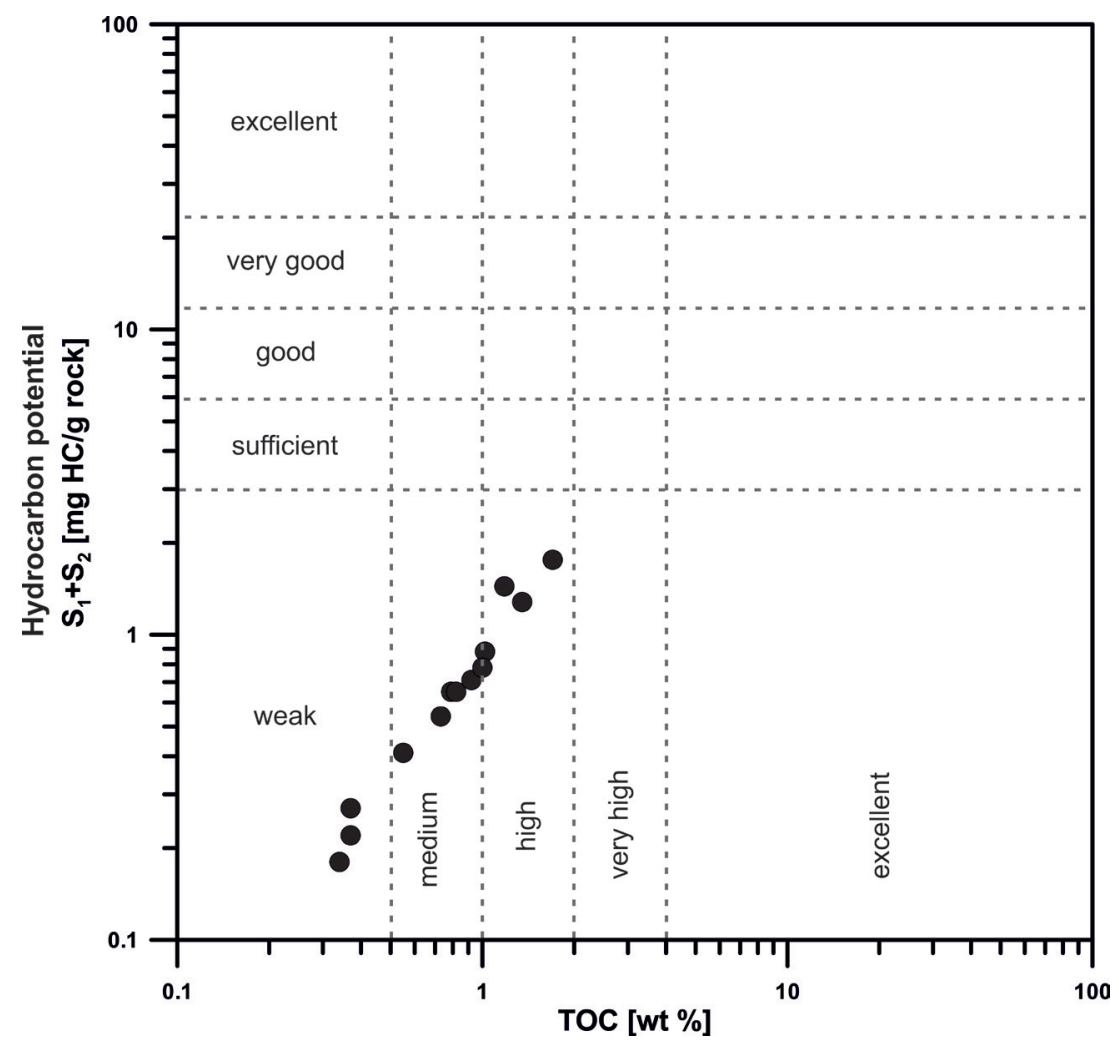

Fig. 9. Petroleum source quality diagram for 13 analyzed samples. Classification after Peters \& Cassa (2002) 

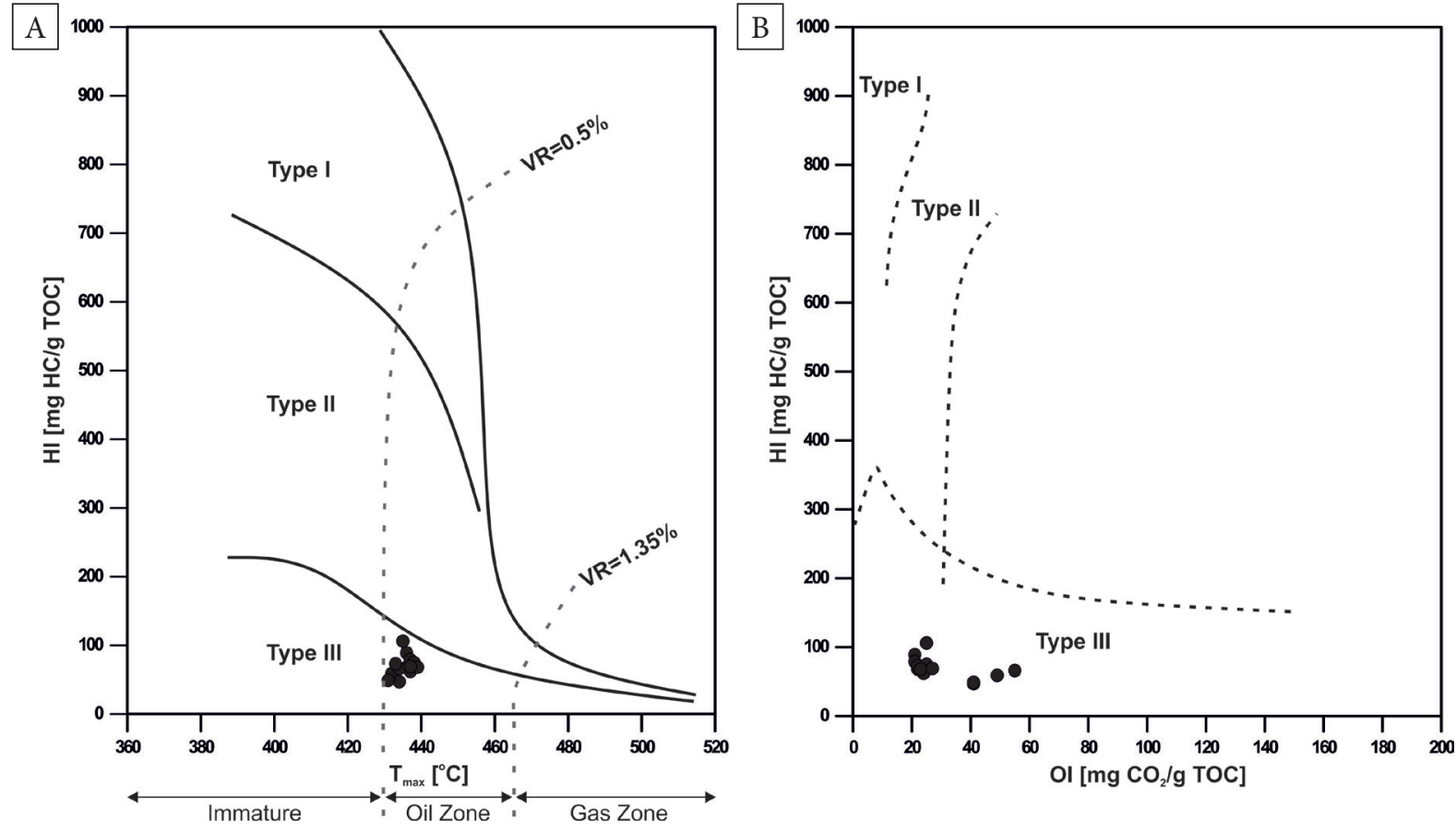

Fig. 10. Plot of hydrogen index (HI) versus temperature Tmax. Alteration curves of different types of kerogen and intervals of thermal maturity after Espitalié et al. 1985 (A); organic matter characterization based on Rock-Eval pyrolysis results (B)

The succession within the shale complexes repeats across the Świątkowa Member deposits. The dark-gray organic-rich shales were observed usually in the lower parts of the shaly complex. The shales gradually change upwards the color and TOC content (Figs. 4, 8). The green organic-poor shales occur in the upper parts of observed complexes. These changes reflect the cyclical character of the turbiditic sedimentation. Two basic factors, supply and preservation of organic matter are most important. These factors are reflected by organisms living in the bottom zones of the basin. The investigation of benthic foraminifera, which were adapted to life in a various marine environments help to characterize the paleoenvironment of organic-rich deposits. These forms are known from different depths and sedimentary regimes, they can inhabit the environments predominated by flysch sedimentation. Their development is dependent on many environmental factors, however, the oxygenation in bottom water of the basin is one of the most important. Foraminifera are the organisms with a very wide ecological tolerance, they can colonize anoxic-dysoxic bottom waters (e.g. Bernhard 1993, Bernhard \& Alve 1996,
Moodley et al. 1997, Langlet et al. 2013, Geslin et al. 2014, Nardelli et al. 2014, Meilijson et al. 2016 and references therein). Somehow the oxygenation on the bottom waters plays a decisive role for the development of specific associations of foraminifera.

Poor oxygenation, hypoxia, and anoxia limit the development of the fauna, and this is reflected in the studied foraminiferal assemblages. A clear correlation between the TOC content and numbers and diversity of foraminifera was observed (Waśkowska et al. 2017). The first type of assemblages was represented only by not numerous, partly pyritized, large sized tubular forms (Fig. 5). It originates from dark mudstone deposits where the TOC amount is the highest and oscillates around 1\% (Tab. 2, Fig. 8). Preservation of organic matter in mudstone sediment originated during turbidity residual sedimentation. It was possible in oxygen deficit or oxygen poor conditions in bottom waters of the basin. That environment was not favorable for development of complex foraminiferal assemblages; it was tolerated by not numerous and most opportunistic forms like Nothia. 
The clear difference between these assemblages and assemblages from the uppermost part of shaly layers is well visible. The second type of assemblages is represented by numerous and diversified agglutinated foraminifera. 38-36 species belonging to the 20-24 genera were recognized (Tab. 2, Figs. 5, 8). Despite the quite high taxonomic diversity, three quarters in the assemblages have tubular forms, Saccamminacea and Lituotubacea. The large proportion of tubular forms as well as Paratrochamminoides and Trochamminoides in assemblages is common during Late Cretaceous-Early Paleogene Carpathian deposition (e.g. Geroch et al. 1967, Jurkiewicz 1967), but the high number of Saccammina and Placentammina is an unknown phenomenon. Relatively high taxonomic diversity is an expression of development of more complex foraminiferal associations but consisting of primitive forms building fairly simple and massive agglutinated tests. The morphology of foraminiferal tests reflects living strategy (after Jones \& Charnock 1985 and later modifications). It is worth to note that assemblages from the upper shaly parts are poor in forms penetrating the upper part of bottom sediment known as infauna. Epifaunal forms living on the surface of bottom sediment dominate. Their share is $85-88 \%$ of all foraminifera; relatively numerous are compact forms, which can efficiently move. The TOC content in the upper part of shaly deposits is from $0.34 \%$ to $0.55 \%$ (Tab. 1, Fig. 8). It is two or three times lower compared on to the lower part. Both, the decrease in the TOC content and more complicated foraminiferal assemblages indicate improvement of the oxygenation in the bottom waters, which were conducive to the development of primitive epifaunal foraminiferal associations.

The oxygen conditions at the seabed zone of the Magura Basin during the sedimentation of turbidities of the Świątkowa Member underwent fluctuations. A poor oxygenation conditions are noticed in dark deposits in lower parts of shaly intervals of the turbidites. The green mudstone from the uppermost parts of layers were deposited in better (low oxygen) conditions. The basinal bottom surface was colonized by agglutinated foraminiferal fauna during the sedimentation of each shale layer. These assemblages evolved to the more complexed in term of diversity and numbers with increase of oxygen content. Generally, sedimentation of the Świątkowa Member deposits took place under oxygen deficiency, which was conducive for preserving organic matter

The following factors enhance organic-richness (Golonka et al. 2009 and reference therein):

\section{BIOLOGIC PRODUCTIVITY}

(Nutrient Concentrating Processes and Settings)

A. Enhanced Nutrient Concentrations

1) Terrestrial Input of Nutrients

2) Coastal Upwelling

3) Open Water Upwelling

B. Evaporitic Settings

1) Silled Basins

2) Shelf/Platform Depressions

3) Rifts on Flooded Continental Platforms

4) Mid and High Latitude Deserts

C. Restricted Geographic Configuration

D. Terrestrial Kerogen Influx

E. High Latitude Effect (Oceanic Convergence)

\section{DEPOSITIONAL PRESERVATION}

(ofOrganic Material in Depositional Environment)

A. Actively Subsiding Depocenter at Time of Deposition

B. Maintenance of Anoxia

1) Positive Water Balance (Fresh-Water Influx)

2) Salinity Stratification

3) Thermal Stratification

4) High Productivity

5) Restricted Circulation (Deep, Narrow Trough or Silled Basin)

C. Isolation Factor

1) Distance of Basin from PaleoShoreline (Coastlines, Shelves, Epeiric Seaways)

2) Local Uplift Deflecting Drainage away from Basin (Rifts)

\section{NON-DILUTION OF SEDIMENTED ORGANIC} MATTER

(Low Sedimentation Rate)

A. Proximity to Orogenic Belts during Interval of Source Rock Deposition

B. Drainage Conduits into Depocenter from Uplifted Areas

C. Rate Influence by Climatic Belts, e.g. Wet Zones. 
The detailed discussion concerning the above mentioned factors was provided in the Golonka et al. (2009) paper. The paleogeographic position indicates that the Siary Zone within Magura Basin (Fig. 11) fulfills certain conditions for organic productivity during Late Cretaceous-Paleocene times.

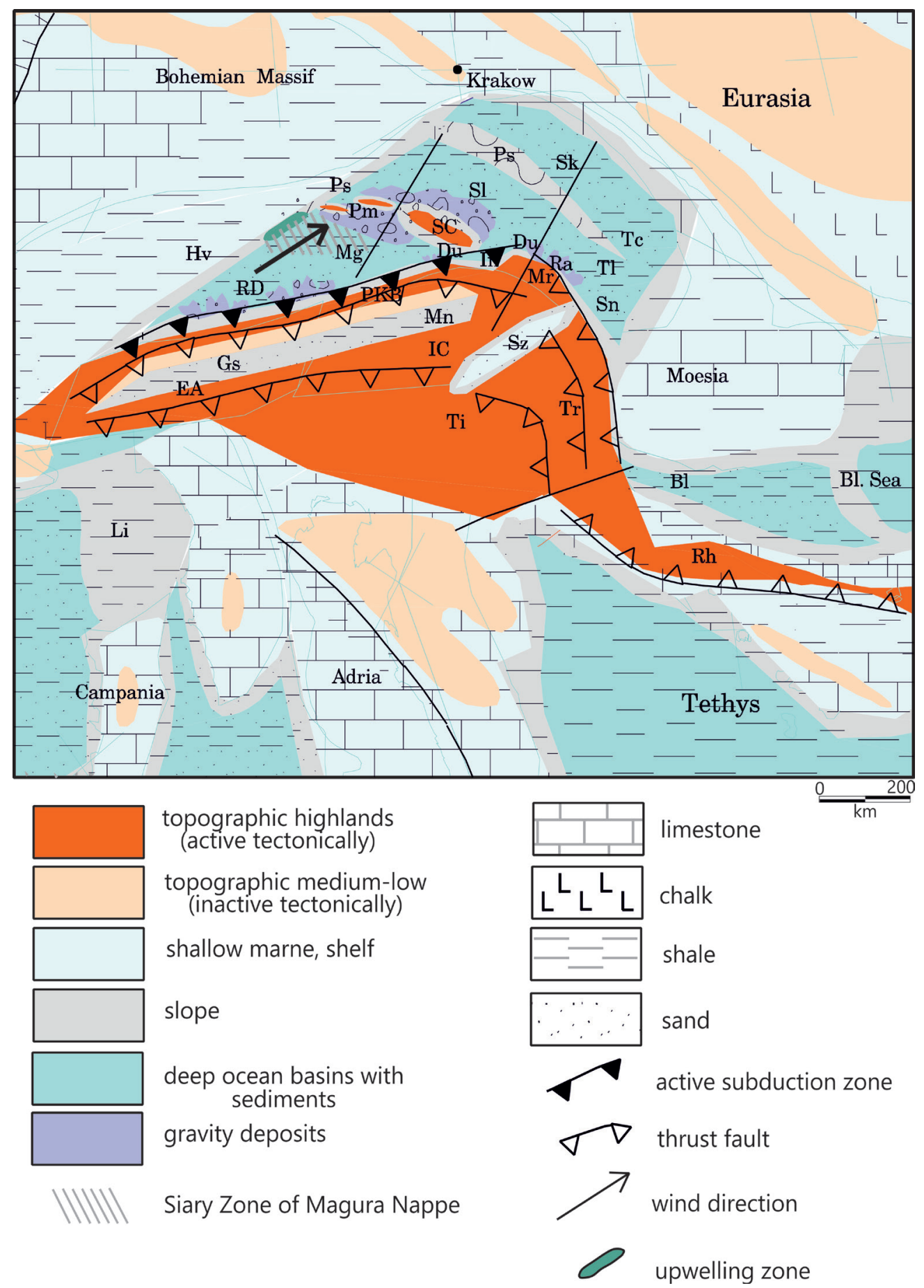

Fig. 11. Paleogeography of the Western Tethys in the Paleocene (after Golonka et al. 2006 - modified). Abbreviations: Bl - Balkan Basin and foldbelt, Du - Dukla Basin, EA - Eastern Alps, Gs - Gresten Basin, Hv - Helvetic shelf, IC - Inner Carpathians, In - Inacovce-Kricevo zone, Li - Ligurian Basin, Mg - Magura Basin, Mn - Manin Basin, Mr - Marmarosh Massif, PKB - Pieniny Klippen Belt, Pm - Fore-Magura Basin, Ps - Subsilesian Ridge and slope zone, Ra - Rakhiv Basin, RD - Rheno Danubian Basin, Rh - Rhodope Basin and foldbelt, SC - Silesian Ridge (Cordillera), Si - Silesian Basin, Sk - Skole Basin, Sn - Sinaia Basin, Sz - Szolnok Basin, Tc - Tarcau Basin, Ti - Tisa plate, Tl-Teleajen Basin, Tr - Transilvanian Basin 
Paleoclimate modeling indicates wind directions favorable for coastal upwelling during northern hemisphere winter. The origin of many organicrich rocks has been attributed to upwelling (e.g. Brooks \& Fleet 1987, Huc ed. 1995, Summerhayes et al. 1995, De Wever \& Baudin 1996, Rais et al. 2007, Golonka et al. 2009). This is because upwelling zones are rich in dissolved nutrients necessary to sustain high organic productivity. The so-called General Circulation Model suggests connection between paleo-upwelling regimes and marine petroleum source rock occurrence (see Huc ed. 1995, Selwood \& Valdes 2007 with references therein). Terrestrial input of nutrients is indicated by paleogeographic position close to emerging ridges as well as by characteristics of kerogen. The preservation of organic material in the depositional environment is assured by the maintenance of anoxia, active basin subsidence and local uplift of ridges. Most major source rocks, with the exception of prodelta shales and some turbidites and upwelling-related source rocks, show evidence of having been deposited in anoxic or suboxic conditions (Brooks \& Fleet 1987, Tyson \& Pearson 1991, Huc 1995, Meyers 2006), known also from Carpathian basins (Golonka et al. 2009). The non-dilution of sedimented organic matter is somewhat less certain in the synorogenic paleoenvironment. The type of sediment within which organic material is buried also affects organic carbon richness. Studies (Brooks \& Fleet 1987, Klemme \& Ulmishek 1991, Huc ed. 1995) have shown that, on average, clay contains about twice as much organic matter as silt, and silt contains about twice as much as sand. Organic matter is more easily adsorbed to fine-grained sediments (clays) than to coarser-grained sediments, because clay minerals, especially montmorillonite, have nearly 1000 times more surface area by weight than quartz and other sand components (Golonka et al. 2009). Turbiditic claystone sometimes contains more carbon than the hemipelagic claystone that this case of the Carpathian deposits. Rapid deposition of fine-grained sediment seems to be a key factor to preserve organic carbon (Ibach 1982, Stein 1990).

A large input of siliciclastics was present in the southern part of Magura Basin (Fig. 11) close to the Inner Carpathian and Pieniny Klippen Belt. The northern part (Siary Zone) was sourced only by at least partially submerged ridges. Thick-bedded sandstones were deposited only locally (Cieszkowski et al. 2007). Longer episodes of finegrained sedimentation were common during Late Cretaceous-Early Eocene times (Golonka 2011).

The conventional deposits have produced oil and gas in the Siary Zone of Magura Nappe since the $19^{\text {th }}$ century (Fig. 2). Three oil fields occur in the vicinity of investigated area (Karnkowski 1999). The Sękowa-Ropica Górna-Siary field is located in close vicinity to the Sękówka outcrop. It was discovered in 1860. About 208 thousand tons of oil were produced from the Ropianka Formation sandstones. The Męcina Wielka field is $10 \mathrm{~km}$ south-eastward from Gorlice. They were discovered in 1870 and produced over 20 thousand tons of oil from strongly folded Ropianka Formation sandstone complexes. The Szymbark oilfield is located southwestward from Gorlice. It produced 30 thousand tons of oil from the Eocene Łabowa Formation and the Paleocene Ropianka Formation sandstones. The Ropianka deposit is located $50 \mathrm{~km}$ southeastward from Gorlice in the marginal part of the Siary Zone. The oil occurs within the Ropianka Formation sandstones. The shales of this formation form seals. The Ropianka field produced over 30 thousand tons of oil (Karnkowski 1999, Golonka et al. 2017). The crude oil was used in the Gorlice region a long time before the industrial production. The locals used it for cart lubrication and as a medicine to treat baldness. The industrial production was initiated by a local pharmacist, Ignacy Łukasiewicz. He experimented in his pharmacy with crude oil supplies, obtained kerosene and constructed a kerosene lamp, which was widely used in the $19^{\text {th }}$ century. Numerous oil seeps exist in the eastern part of Siary Zone. Several villages and rivers bears the names derived from "ropa" (the Polish name for crude oil) like Ropica, Ropianka, Ropa. Oil was also produced in the western part of the Siary Zone, in the Klęczany and Słopnice-Limanowa oil fields. Gas seeps were discovered recently in Trzebunia village south of Kraków (Golonka et al. 2017, ShaleCarp). The reservoirs of these fields are well known, whereasthe source for these oils and gases remained unknown. The 19 century explorers did not bother with the source rocks and drilled in the vicinity of seeps. It is possible that organic-rich shales of the 
Swiątkowa Member were the source rocks supplying surrounding fields. In this case some organic-rich rocks, source for conventional deposits can be transferred into unconventional hydrocarbon systems. Occurrences of conventional deposits, oil and gas seeps sourced by organic-rich shales as well as results of presented research justify further investigation of organic-rich deposits within the Siary Zone of the Magura Nappe in Poland in order to evaluate the possibility of unconventional gas resources. The presented investigation constitutes the first step, and more complete sampling program, especially from bore-holes, is needed to refine our estimate. The relatively unexplored area south of Kraków appears most promising.

\section{CONCLUSIONS}

Dark gray and green shales which contain different TOC content and the varied foraminifera assemblages occur within the turbidites of the Świątkowa Member. The dark parts with the TOC up to $1.7 \mathrm{wt}$.\% contain poor foraminiferal assemblages, which development was limited by poor oxygen condition. Upwards turbidite sequence, in the green parts with lower TOC content, the improvement of oxygen conditions is observed that is expressed by occurrence of numerous and more diversified agglutinated foraminifera. They are represented mainly by primitive cosmopolitan taxa suggesting better but still limited oxygen conditions on the Magura Basin floor. The dominance of the dark shales is typical for the Swiątkowa Member. Its depositional environment fostered the preservation of the organic matter. Features of the Świątkowa Member of the Ropianka Formation indicate that these deposits have features of the hydrocarbon source rocks.

The thanks are addressed to reviewers for constructive comments to manuscript. The authors are grateful to prof. Irena Matyasik (INiG) for sample pyrolysis, Marta Waliczek (AGH) for reflectance measurements and Aleksandra Durek (AGH) for laboratory work. This research has been financially supported by the National Centre for Research and Development Blue Gas Program (BG2/ShaleCarp/14) and Statutory funds of KGOiG WGGiOS AGH.

\section{REFERENCES}

ASTM D7708-11, 2011. Standard Test Method For Microscopical Determination of the Reflectance of Vitrinite Dispersed in Sedimentary Rocks. [in:] Annual Book of ASTM Standards: Petroleum Products, Lubricants, and Fossil Fuels; Gaseous Fuels; Coal and Coke, Sec. 5, v. 5.06, ASTM International, West Conshohocken, PA, 823-830.

ASTM D7708-14, 2014. Standard Test Method for Microscopical Determination of the Reflectance of Vitrinite Dispersed in Sedimentary Rocks. ASTM International, West Conshohocken, [on-line:] www.astm.org [access: 28.01.2018]

Barker C., 1974. Pyrolysis techniques for source-rock evaluation. AAPG Bulletin, 58, 2349-2361. DOI: 10.1306/83D91BAF-16C7-11D7-8645000102C1865D [access: 25.01.2018].

Barker C.E. \& Pawlewicz M.J., 1993. An empirical determination of the minimum number of measurements needed to estimate the mean random vitrinite reflectance of disseminated organic matter. International Journal of Coal Geology, 20, 643-651.

Bernhard J.M., 1993. Experimental and field evidence of Antarctic foraminiferal tolerance to anoxia and hydrogen sulfide. Marine Micropaleontology, 20, 203-213. DOI: 10.1016/0377-8398(93)90033-T.

Bernhard J.M. \& Alve E., 1996. Survival, ATP pool, and ultrastructural characterization of benthic foraminifera from Drammensfjord (Norway): response to anoxia. Marine Micropaleontology, 28, 5-17. DOI: 10.1016/03778398(95)00036-4.

Brooks J. \& Fleet A.J. (eds.), 1987. Marine Petroleum Source Rocks. Geological Society Special Publication, 26, Blackwell Scientific Publications, Oxford.

Cieszkowski M., Golonka J., Waśkowska-Oliwa A. \& Chodyń R., 2007. Type Locality of the Mutne Sandstone Member of the Jaworzynka Formation, Western Outer Carpathians, Poland. Annales Societatis Geologorum Poloniae, 77, 269-290.

De Wever P. \& Baudin F., 1996. Palaeogeography of radiolarite and organic-rich deposits in Mesozoic Tethys. Geologische Rundschau, 85, 310-326.

Espitalié J., Deroo G. \& Marquis F., 1985. La pyrolyse RockEval et ses applications. Deuxième partie. Revue de l'Institut Francais du Petrole, 40, 755-784. DOI: 10.2516/ ogst:1985045.

Geroch S., Jednorowska A., Książkiewicz M. \& Liszkowa J., 1967. X Europejskie Kolokwium Mikropaleontologiczne w Polsce - 1967. Część II. Biuletyn Państwowego Instytutu Geologicznego, 221, 185-407.

Geroch S. \& Koszarski L., 1988. Agglutinated foraminiferal stratigraphy of the Silesian flysch trough. Abhandlungen der Geologischen Bundesanstalt, 41, 73-79.

Geroch S. \& Nowak W., 1984. Proposal of zonation for the late Tithonian-late Eocene, based upon arenaceous Foraminifera from the Outer Carpathians, Poland. [in:] Oertli H.J. (ed.), Benthos '83: 2e Symposium International Sur Les Foraminifères Benthiques: Pau (France), 11-15/4/1983, Elf-Aquitane, 225-239.

Geslin E., Barras C., Langlet D., Nardelli M., Kim J.-H., Bonnin J., Metzger E. \& Jorissen F.J., 2014. Survival, reproduction and calcification of three benthic foraminiferal 
species in response to experimentally induced hypoxia. [in:] Kitazato H. \& Bernhard J.M. (eds.), Experimental Approaches in Foraminifera: Collection, Maintenance and Experiments, Springer, Berlin, 163-193.

Golonka J., 2011. Evolution of the Outer Carpathian Basins. [in:] Bąk M., Kaminski M.A. \& Waśkowska A. (eds.), Integrating Microfossil Records from the Oceans and Epicontinental Seas, Grzybowski Foundation Special Publication, 17, Grzybowski Foundation, 3-14.

Golonka J., Gahagan L., Krobicki M., Marko F., Oszczypko N. \& Ślączka A., 2006. Plate Tectonic Evolution and Paleogeography of the Circum-Carpathian Region. [in:] Golonka J. \& Picha F. (eds.), The Carpathians and their foreland: Geology and hydrocarbon resources, American Association of Petroleum Geologists Memoir, 84, AAPG, 11-46. DOI: 10.1306/985606M843066.

Golonka J., Krobicki M., Waśkowska A., Matyasik I., Pauken R., Bocharova N.J., Edrich M. \& Wildharber J., 2009. Source Rock Prediction Value: World provinces during Late Jurassic-earliest Cretaceous times and position of West Carpathians in SRPV prediction. Annales Societatis Geologorum Poloniae, 79, 175-185.

Golonka J., Pietsch K. \& Marzec P., 2011. Structure and Plate Tectonic Evolution of the Northern Outer Carpathians. [in:] Closson D. (ed.), Tectonics, InTech, Rijeka, Croatia, 65-92, DOI: 10.5772/14023.

Golonka J., Machowski G., Pietsch K., Waśkowska A. \& Starzec K., 2017. The geological structure and unconventional hydrocarbon potential of the Polish Outer Carpathians. [in:] SGEM 2017: Science and technologies in geology, exploration and mining, Applied and environmental geophysics oil and gas exploration, Albena, Bulgaria, 29 June-5 July 2017, $17^{\text {th }}$ International Multidisciplinary Scientific Geoconference: conference proceedings, 17, STEF92 Technology Ltd., Sofia, 933-940.

Horsfield B., 1984. Pyrolysis studies and petroleum exploration. [in:] Brooks J. \& Welte D. (eds.), Advances in Petroleum Geochemistry, 1, Academic Press, London, 247-298. DOI: 10.1016/B978-0-12-032001-1.50010-9.

Huc A.-Y. (ed.), 1995, Paleogeography, Paleoclimate, and Source Rock. AAPG Studies in Geology Series, 40, American Association of Petroleum Geologists.

Ibach L.E.J., 1982. Relationship between sedimentation rate and total organic carbon content in ancient marine sediments. AAPG Bulletin, 66, 170-188.

Jones R.W. \& Charnock M.A., 1985. "Morphogrups" of agglutinated Foraminifera, their life positions and feeding habitats and potential applicability in (paleo)ecological studies. Revue de paléobiologie, 4, 311-320.

Jurkiewicz H., 1967. Foraminifers in the sub-Menilitic Palaeogene of the Polish Middle Carpathians. Biuletyn Państwowego Instytutu Geologicznego, 210, 5-128.

Jurkiewicz H. \& Karnkowski P., 1959. Age of the Inoceramian beds in the Magura Nappe in Gorlice area. Acta Geologica Polonica, 9, 17-54.

Kaminski M.A. \& Gradstein F.M., 2005. Atlas of Paleogene cosmopolitan deep-water agglutinated foraminifera. Grzybowski Foundation Special Publication, 10, Grzybowski Foundation, 548. DOI: 10.2113/gsmicropal.52.6.555.

Kaminski M.A. \& Ślączka A., 1998. Guidebook to excursions in the Polish Flysch Carpathians. Grzybowski Foundation Special Publication, 6, Grzybowski Foundation.
Karnkowski P., 1999. Oil and Gas Deposits in Poland. Wydawnictwo Geos, Kraków.

Klemme H.D. \& Ulmishek G.F., 1991. Effective petroleum source rocks of the world: stratigraphic distribution and controlling depositional factors. AAPG Bulletin, 75, 1809-1851.

Kopciowski R., Zimnal Z., Chrząstowski J., Jankowski L. \& Szymakowska F., 1997a. Szczegółowa mapa geologiczna Polski 1:50 000. Arkusz Gorlice. PIG-PIB, Warszawa.

Kopciowski R., Zimnal Z. \& Jankowski L., 1997b. Szczegółowa mapa geologiczna Polski 1:50 000. Arkusz Osiek Jasielski. PIG-PIB, Warszawa.

Kopciowski R., Zimnal Z., Chrząstowski J., Jankowski L. \& Szymakowska F., 2014. Objaśnienia do Szczegółowej mapy geologicznej Polski 1:50 000. Arkusz Gorlice. PIG-PIB, Warszawa.

Koszarski J., Sikora W. \& Wdowiarz S., 1974. The flysch Carpathians. [in:] Mahel M. (ed.), Tectonics of the Carpathian-Balkan Regions, Explanations to the Tectonic Map of the Carpathian-Balkan Regions and their Foreland, Štátny geologický ústav Dionýza Štúra, Bratislava, 180-197.

Kotarba M.J. \& Koltun Y.V., 2006. The origin and habitat of hydrocarbons of the Polish and Ukrainian parts of the Carpathian Province. [in:] Golonka J. \& Picha F. (eds.), The Carpathians and their foreland: Geology and hydrocarbon resources, American Association of Petroleum Geologists Memoir, 84, AAPG, 395-443. DOI: $10.1306 / 985605 \mathrm{M} 843074$.

Kováč M., Nagymarosy A., Oszczypko N., Ślączka A., Csontos L., Marunteanu M., Matenco L. \& Márton M., 1998. Palinspastic reconstruction of the Carpathian-Pannonian region during the Miocene. [in:] Rakús M. (ed.), Geodynamic development of the Western Carpathians: Geological Survey of Slovac Republic, Dionýz Štúr Publishers, Bratislava, 189-217.

Krobicki M., Golonka J. \& Ślączka A., 2012. The Carpathians - Menilite Shale as the main oil source in the Carpathians: Field trip, leaders: Michał Krobicki, Jan Golonka; with Contribution of Andrzej Ślączka. [in:] GeoShale 2012: Recent Advances in Geology of Fine-grained Sediments: International Conference, $14^{\text {th }}-16^{\text {th }}$ May 2012, Warsaw, Poland, Book of abstracts, Field trip guidebook, Polish Geological Institute - National Research Institute, Warsaw, 195-233.

Lafargue E., Marquis F. \& Pillot D., 1998. Rock-Eval 6 Applications in Hydrocarbon Exploration, Production, and Soil Contamination Studies. Oil \& Gas Science and Technology, 53, 421-437. DOI: 10.2516/ogst:1998036.

Langlet D., Geslin E., Baal C., Metzger E., Lejzerowicz F., Riedel B., Zuschin M., Pawlowski J., Stachowitsch M. \& Jorissen F.J., 2013. Foraminiferal survival after longterm in situ experimentally induced anoxia. Biogeosciences, 10, 7463-7480. DOI: 10.5194/bg-10-7463-2013.

Meilijson A., Ashckenazi-Polivoda S., Illner P., Alsenz H., Speijer R.P., Almogi-Labin A., Feinstein S., Püttmann W. \& Abramovich, S., 2016. Evidence for specific adaptations of fossil benthic foraminifera to anoxic-dysoxic environments. Paleobiology, 42, 77-97. DOI: 10.1017/ pab.2015.31.

Meyers P.A., 2006. Paleoceanographic and paleoclimatic similarities between Mediterranean sapropels and Cretaceous black shales. Palaeogeography, Palaeoclimatology, Palaeoecology, 235, 305-320. 
Moodley L., Van Der Zwaan G.J., Herman P.M.J., Kempers L. \& Van Breugel P., 1997. Differential response of benthic meiofauna to anoxia with special reference to Foraminifera (Protista: Sarcodina). Marine Ecology Progress Series, 158, 151-163. DOI: 10.3354/meps158151.

Nardelli M.P., Barras C., Metzger E., Mouret A., Filipsson H.L., Jorissen F. \& Geslin E., 2014. Experimental evidence for foraminiferal calcification under anoxia. Biogeosciences, 11, 4029-4038. DOI: 10.5194/bg-11-4029-2014.

Olszewska B., 1997. Foraminiferal biostratigraphy of the Polish Outer Carpathians: a record of basin geohistory. Annales Societatis Geologorum Poloniae, 67, 325-337.

Olszewska B., Odrzywolska-Bieńkowa E., Giel M.D., Pożaryska K. \& Szczechura K., 1996. Rząd Foraminiferida Eischwald Order Foraminiferida Eichwald, 1830. [in:] Limanowska L. \& Piwocki M. (red.), Budowa geologiczna Polski. T. 3, Atlas skamieniałości przewodnich i charakterystycznych. Część 3a. Kenozoik, trzeciorzęd, paleogen, Polska Agencja Ekologiczna, Warszawa, 45-215.

Oszczypko N., Ślączka A. \& Żytko K., 2008. Tectonic subdivision of Poland: Polish Outer Carpathians and their foredeep. Przeglad Geologiczny, 56, 927-935.

Peters K.E. \& Cassa M.R., 2002. Applied source rocks geochemistry. [in:] Magoon L.B. \& Dow W.G. (eds.), The Petroleum system - from source to trap, AAPG Memoir, 60, American Association of Petroleum Geologists, 93-121. DOI: 10.1306/M60585C5.

Rais P., Louis-Schmid B., Bernasconi S.M. \& Weissert H., 2007. Palaeoceanographic and palaeoclimatic reorganization around the Middle-Late Jurassic transition. $\mathrm{Pa}$ laeogeography, Palaeoclimatology, Palaeoecology, 251, 527-546.

Sellwood B.W. \& Valdes P.J., 2006. Mesozoic climates: General circulation models and the rock record. Sedimentary Geology, 190, 269-287.

ShaleCarp: research project of Polish Oil and Gas Company and AGH University of Science and Technology in Kraków, https://www.researchgate.net/project/AcronymShaleCarp [access: 28.01.2018].

Stein R., 1990. Organic carbon content/sedimentation rate relationship and its paleoenvironmental significance for marine sediments. Geo-Marine Letters, 10, 37-44.

Summerhayes C.P., Emeis K.-C., Angel M.V., Smith R.L. \& Zeitzschel B. (eds.), 1995. Upwelling in the ocean: modern processes and ancient records. Dahlem Workshop Reports, 18, Wiley.

Sztejn J., Liszkowa J., Morgiel J. \& Szymakowska F., 1984. Phylum Protista, Class Reticularea Lankester, 1885, Order Foraminiferida Eichwald, 1830. [in:] Malinowska L. (ed.), Budowa geologiczna Polski. T. 3, Atlas skamieniatości przewodnich i charakterystycznych. Cz. 2c, Mezozo$i k$ : kreda, Wydawnictwa Geologiczne, Warszawa, 28-89.

Ślączka A., 2003. Budowa geologiczna [in:] Górecki A., Krzemień K., Skib S. \& Zemanek B. (eds.), Przyroda Magurskiego Parku Narodowego, Magurski Park Narodowy Uniwersytet Jagielloński, Krempna - Kraków, 13-19.
Ślączka A., 1993, The origins of applied Micropaleontology. The School of Józef Grzybowski. Grzybowski Foundation Special Publication, 1, Grzybowski Foundation.

Ślączka A., Geroch S. \& Koszarski L., 1993. Exposure 3. Ropica. [in:] Gasiński M.A. \& Malata E. (eds.), IV International Workshop on Agglutinated Foraminifera: Excursion Guidebook Polish Flysch Carpathians, Grzybowski Foundation Special Publication, 2, Grzybowski Foundation, 13-15.

Ślączka A., Kruglow S., Golonka J. Oszczypko N. \& Popadyuk I., 2006. The General Geology of the Outer Carpathians, Poland, Slovakia, and Ukraine. [in:] Golonka J. \& Picha F. (eds.), The Carpathians and their foreland: Geology and hydrocarbon resources, American Association of Petroleum Geologists Memoir, 84, AAPG 221-258.

Ślączka A., Golonka J., Oszczypko N., Cieszkowski M., Słomka T. \& Matyasik I., 2014. Occurrence of the Upper Jurassic-Lower Cretaceous black organic-rich pelitic sediments as targets for unconventional hydrocarbon exploration in the Outer Carpathians and adjacent part of Alps. AAPG Bulletin, 98, 1967-1994. DOI: $10.1306 / 02211413049$

Swierczewska A., 2005. The interplay of the thermal and structural histories of the Magura Nappe (Outer Carpathians) in Poland and Slovakia. The Mineralogia Polonica, 36, 91-144.

Świerczewska A., Tokarski A.K. \& Kozłowski A., 1999. Early brittle tectonics and mineralization of Inoceramian beds. [in:] $5^{\text {th }}$ Carpathian Tectonic Workshop, Poprad-Szymbark, 5-9 th June 1999, Institute of Geological Sciences, Polish Academy of Sciences, Krakow, 39-40.

Tyson R.V. \& Pearson T.H., 1991. Modern and ancient continental shelf anoxia: an overview. [in:] Tyson R.V. \& Pearson T.H. (eds.), Modern and Ancient Continental Shelf Anoxia, Geological Society Special Publication, 58, Geological Society, London, 1-24.

Waśkowska A., Golonka J. \& Machowski G., 2017. Agglutinated foraminifera from changing oxygen conditions in Paleocene turbidities (Outer Carpathians, Poland) preliminary results. [in:] Soták J., Kaminski M.A., Fekete K. \& Kowal-Kasprzyk J. (eds.), Tenth International Workshop on Agglutinated Foraminifera, Grzybowski Foundation Special Publication, 23, Grzybowski Foundation, 88-89.

Waśkowska-Oliwa A., 2008. The Paleocene assemblages of agglutinated foraminifera from deep-water basin sediments of the Carpathians (Subsilesian Unit, Poland) biostratigraphical remarks. [in:] Kaminski M. \& Coccioni R. (eds.), Proceedings of the Seventh International Workshop on Agglutinated Foraminifera, Grzybowski Foundation Special Publication, 13, Grzybowski Foundation, 227-265.

Wilczek T. \& Merta H., 1992. Wstępne wyniki badań pirolitycznych metodą Rock-Eval. Wstępna ocena macierzystości wybranych utworów. Nafta, 48, 109-116. 